\title{
An Integrated Interval type 2 fuzzy AHP and COPRAS-G methodologies for supplier selection in the era of Industry 4.0
}

Sema Kayapinar Kaya ( $\sim$ semakayapinar@munzur.edu.tr )

Munzur Universitesi https://orcid.org/0000-0002-8575-4965

Ejder Aycin

Kocaeli Universitesi

\section{Original Article}

Keywords: Industry 4.0, supplier selection, Interval type 2 fuzzy set, AHP, COPRAS-G

Posted Date: January 29th, 2021

DOl: https://doi.org/10.21203/rs.3.rs-168876/v1

License: (c) (i) This work is licensed under a Creative Commons Attribution 4.0 International License.

Read Full License

Version of Record: A version of this preprint was published at Neural Computing and Applications on March 10th, 2021. See the published version at https://doi.org/10.1007/s00521-021-05809-x. 


\title{
An Integrated Interval type 2 fuzzy AHP and COPRAS-G methodologies for supplier selection in the era of Industry 4.0
}

\author{
Sema Kayapinar Kaya \\ Assistant Professor \\ Munzur University, Faculty of Engineering, \\ Department of Industrial Engineering, \\ semakayapinar@munzur.edu.tr
}

Orcid ID: 0000-0002-8575-4965

\section{Ejder Aycin}

Assistant Professor

Kocaeli University Faculty of Business and Administrative Sciences, Department of Business Administration,

ejder.aycin@kocaeli.edu.tr

Orcid ID: 0000-0002-0153-8430

\begin{abstract}
Supply chain has a very extensive and dynamic structure that incorporates new business models, new customer expectations, market searches and technological developments. With the introduction of Industry 4.0 into supply chain, a rapid and intensive process of digitalization begin to transform every step of supply chain. Supply chain selection is one of the essential decisions in reducing the supply chain cost and improving overall quality of product and services. With the implication of digital technologies and Industry 4.0 on supply chain, the supplier selection process has been significantly changed during the recent years. Companies are willing to need new requirements for their own suppliers in accordance with Industry 4.0 implementations and technologies. This paper aims to identify key criteria to Industry 4.0 technologies and evaluate them to select the right suppliers selection in the era of Industry 4.0 Within the scope of this study attempts to develop an integrated Interval Type 2 Fuzzy AHP and GOPRAS-G methodology to select the appropriate supplier in the face of Industry 4.0 implementations. For this purpose, Interval Type 2 Fuzzy AHP was employed to weight the supplier evaluation criteria and then, Grey COPRAS method has been applied to prioritize suppliers. This paper is to provide practitioners and researchers with insight into how Industry 4.0 strategies influence on supplier selection.
\end{abstract}

Keywords: Industry 4.0, supplier selection, Interval type 2 fuzzy set, AHP, COPRAS-G 


\section{Introduction}

The Forth Industrial Revolution, also known as "Industry 4.0" is defined as the full integration and digitalization of the industrial value creation. Digital transformation means the high-advanced technologies that transform existing manufacturing and industrial practices with the Technologies world. Industry 4.0 is a collection of systems consisting of many different advanced technology components [1]. These technological innovations such as Internet of Things (IoT), cloud computing, artificial intelligence, augmented reality, human to machine / machine to machine interfaced, cyber-physical systems (CPS), cognitive computing, autonomous robots, the advanced and sophisticated intelligence methods are the backbone of Industry 4.0 concepts. All state-of-the-art technologies employ the complicated and advanced artificial intelligence (AI) algorithms to operate manufacturing and industrial processes. Machine learning, deep learning and AI based practices such as the least square support vector machine (LSSVM) and artificial neural network (ANN) are the most preferable and suitable algorithms for creating, conducting and optimizing the industrial operations. Artificial Intelligence-based Industry 4.0 technologies brings significant development in many industrial sectors [2,3,4]. They help manufacturers with current challenges by becoming greater efficiency and flexibility along the whole operational and industrial practices.

The supply chain is the core of all operational activity of manufacturing companies and plays a key element in gaining competitive advantage among competitors. All changes in production will be directly reflected in supply chain. The implementation of a wide range of industry 4.0 technologies will transform traditional supply chain into digital supply chain. Supply chain digitalization means the integration of physical supply chain processes with digital data to improve supply chain efficiency. The digitization of the supply chain has significant influence on company by increasing great visibility along the supply chain. A digital supply chain has many techniques that monitor real-time items, reduce the idle time in production, visualize a smart interconnected network, make more efficient use of resources, optimizing supply chain inventories to enabling supplier risk assessment, provide great visibility along the supply chain. For example, the IoT is one of the most important technology that starts the digital transformation of supply chains. IoT can regularly monitor, automatically track all the relevant information (e.g. route, shipping conditions, and status of shipment) and remotely control throughout supply chain. With use of IoT application, IoT-generated data can be rapidly transfer among supply chain organizations (supplier, manufacturer, retailer, customer) and it is possible to make faster and more effective supply chain decisions.

Supplier selection plays a critical role in gaining competitive advantage among organizations. Choosing the right supplier ensure goods at the right time, at the right place with the right quantity in the right condition for the right customer. The supplier selection process has a complicated structure that involve multiple criteria such as price, quality, flexibility, labor relations, capability. With the implication of digital technologies and Industry 4.0 on supply chain, the supplier selection process has been significantly changed during the recent years. Companies are willing to need new requirements for their own suppliers in accordance with Industry 4.0 implementation process. Suppliers also investigate in Industry 4.0 and the integrated process to meet different standards for their various customers. There is insufficient study on the supplier evaluation in the context of Industry 4.0.

They are various supplier selection methods such as Data Envelopment analysis (DEA), Multi criteria decision making (MCDM) techniques, linear and goal programming, artificial neural network (ANN) and combined methods to use by researchers and practitioners [5]. Sepehriar et al. proposed a linear mathematical modelling to weights of supplier selection criteria under fuzzy environment [6]. Fallahpour et al. developed a hybrid model combined with AHP and multi expression programming (MEP) for supplier selection problem [7]. Supplier selection is a strategic decision problem that consider several conflicting criteria for selecting the best supplier from a variety of supplier. MCDM methods are commonly preferred in supplier selection problems because it can handle both qualitative and / or qualitative criteria.

The concept of a type-2 fuzzy set was developed by Zadeh as an extension of type-1 fuzzy sets (T1FSs) because T1FSs are unable to deal with the uncertainties that currently occur in real-life problem [8,9,10]. Type -2 fuzzy sets (T2FSs) is substantially better than traditional fuzzy set with regards to covering all the uncertainties and vagueness [11]. Furthermore, IT2FSs set can produce more precise and robust results compared to T1FS [12]. Despite these advantages, T2FSs require undesirably large amount of computations and excessive mathematical formulas for solving problems [13]. To reduce the complex computational efforts and manage uncertainty, Interval type 2 fuzzy sets (IT2FS) recommended by researchers. The reduction on the computational complexity is thanks to the new membership function that contribute additional degree of freedom for IT2FSs. Many researchers have employed IT2FSs in the real-world MCDM problems under uncertain and ambiguous environment [14].

Supplier selection is a multi-criteria decision-making problem, which includes multiple and conflict criteria. This study proposes a new hybrid MCDM methodology that is used for the first time in the literature. For this purpose, the concept of Interval type-2 fuzzy sets (IT2FSs) extension of the Analytic Hierarchy process (AHP) is recommended to weight the supplier evaluation criteria. Then, Complex Proportional Assessment method with Grey interval numbers (COPRAS-G) method is employed for identifying the relative importance and ranking supplier alternatives. Interval type-2 fuzzy AHP (IT2F-AHP), was originally developed by [73], provides many 
advantages compared to classical AHP and type-1 fuzzy AHP. IT2F-AHP can better handle uncertainties and vagueness of decision-making problem [15] Additionally, IT2F-AHP can easily reduce the uncertainty from decision-makers' opinion in the comparison matrix. Consequently, this feature of IT2F-AHP method, which makes the linguistic evaluations of decision makers more effective and more flexible, makes it superior to other similar methods [15]. The benefit of COPRAS-G is as follows: (i) having a few calculation steps and short calculation time compared to AHP and TOPSIS method, (ii) COPRAS method has the possibility of calculating the values to be maximized and minimized separately among the criteria [11]. (iii) Typical distribution of samples is not required, (iv) The calculated utility degree indicates how much the best alternative is better than the other in percentage expression compared to other MCDM methods [16]. In this study, all evaluation criteria are subjective, and the values of criteria cannot be expressed exactly. Therefore COPRAS-G method can conveniently express the real condition of decision-making problem with using grey values. This hybrid model can provide better representation of vagueness with simplified calculations.

Selecting the appropriate supplier plays a vital role to success global market and enhance their competitive advantage. Although there are many studies about supplier selection, there are no studies considering industry 4.0 applications in supplier selection. The proposed approach was applied to the high- advanced textile industry to select a best supplier based on Industry 4.0 strategy. In this study, the selected case company aimed to implement heavily in innovative technologies to reduce production costs and to gain the competitive advantage in the global market. For this purpose, Industry 4.0 strategy and implementation has already started and adopted to real-life supplier selection problem for the textile industry. Therefore, this paper proposes an integrated MCDM method to choose which supplier is well-suited to the textile manufacturer. Specifically, the originality of this paper is summarized as follows: (i) This study is the first to consider Industry 4.0 factors in supplier selection under the vagueness environment. This study is substantially different than the other supplier selection problem that consider traditional supplier criteria as well as industry 4.0 criteria. (ii) A hybrid MCDM model encompassing IT2F-AHP and COPRAS-G methodology was proposed. (iii) A real case study was carried out for the advanced textile composite industry. This case study highlighted how to the framework of Industry 4.0 influence on supplier evaluation for the industry and the contribution followed can be easily adapted to another sector in this regard. (iv) A new integrated IT2F-AHP and COPRAG-G method is used the first time in the literature. As a result, IT2FAHP can be clearly deal with uncertainty in the comparison matrices as compared to type- 1 fuzzy set theory and then, COPRAG-G method uses a ranking procedure of the alternatives based on their significance and utility degrees.

The rest of the paper is presented as follows: A literature review regarding supply chain and supplier selection is presented in the next section. The proposed methodology by integrated IT2F-AHP and COPRAS-G are discussed in the Section 3. The illustrative example of Supplier selection for textile manufacturer is expressed in the following section. Sensitivity analysis of proposed model is presented in Section 5. Managerial implication is given in Section 6. Finally, conclusions of this implications, limitations, comparison with the existing literature and future studies are outlined in the Section 7.

\section{Literature Review}

In this section, a literature review is presented of integrated MCDM methods that were used for the supplier selection problem. Extensive hybrid MCDM approaches have been proposed for supplier selection, such as the fuzzy AHP [17, 18, 19], fuzzy ANP [20, 21], fuzzy TOPSIS [22, 23], fuzzy VIKOR [24], interval type 2 fuzzy AHP[15], interval type 2 fuzzy TOPSIS [25], fuzzy AHP and MABAC [26]. Table 1 lists some integrated methods to deal with the problem of supplier selection.

Table 1. Hybrid multi criteria decision making methods applied to supplier selection

\begin{tabular}{|c|c|c|}
\hline Methods & Proposed by & Additional features \\
\hline \multirow{9}{*}{ Fuzzy AHP } & Kahraman et al [27] & Comparing the suppliers based on fuzzy AHP in manufacturing sector. \\
\hline & Chan \& Kumar [28] & Supplier selection considering risk factors \\
\hline & Bottani \& Rizzi [29] & Fuzzy AHP based clustering analysis to reduce lead time \\
\hline & Lee [30] & Benefit, opportunity, cost, and risk model \\
\hline & Chamodrakas et al. [31] & Interval valued pairwise comparison in electronic marketplaces \\
\hline & Sen et al. [32] & Fuzzy AHP and max-min method \\
\hline & Amid et al. [33] & Decision model based on weighted max-min method and AHP \\
\hline & Kilincci \& Onal [34] & Fuzzy AHP approach regarding washing machine company \\
\hline & Chen \& Chao [35] & $\begin{array}{l}\text { AHP model for structure of criteria and consistent fuzzy preference } \\
\text { relations to construct decision matrices. }\end{array}$ \\
\hline \multirow{2}{*}{$\begin{array}{l}\text { Fuzzy } \\
\text { AHP\&TOPSIS }\end{array}$} & Wang et al. [36] & $\begin{array}{l}\text { Fuzzy hierarchical TOPSIS approach for selecting lithium-ion battery } \\
\text { protection supplier }\end{array}$ \\
\hline & Zeydan et al. [37] & $\begin{array}{l}\text { Evaluating performance of suppliers based on qualitative and } \\
\text { quantitative variables in manufacturing factory }\end{array}$ \\
\hline
\end{tabular}




\begin{tabular}{|c|c|c|}
\hline & $\begin{array}{l}\text { Kannan et al. [38] } \\
\text { Junior et al. [39] } \\
\text { Jain et. al [40] }\end{array}$ & $\begin{array}{l}\text { Integrated approach for supplier selection and order allocation in a green } \\
\text { environment. } \\
\text { Comparing two methods based on a set of criteria } \\
\text { A case study of supplier selection using fuzzy AHP and TOPSIS }\end{array}$ \\
\hline Fuzzy ANP & $\begin{array}{l}\text { Amin \& Razmi [41] } \\
\text { Razmi et al. [42] } \\
\text { Önüt et al. [43] } \\
\text { Büyüközkan \& Cifci [44] } \\
\text { Vinodh et al. [45] }\end{array}$ & $\begin{array}{l}\text { A case study of internet service provider selection with integrated fuzzy } \\
\text { model. } \\
\text { Designing a decision model using fuzzy ANP and a numerical sample } \\
\text { A case study for a telecommunication company } \\
\text { A fuzzy MCDM framework wit incomplete information } \\
\text { A case study regarding manufacturing industry. }\end{array}$ \\
\hline Fuzzy TOPSIS & $\begin{array}{l}\text { Chen et al. [46] } \\
\text { Boran et al. [47] } \\
\text { Büyüközkan \& Ersoy [48] } \\
\text { Awasthi et al. [49] } \\
\text { Liao and Kao [50] }\end{array}$ & $\begin{array}{l}\text { An integrated fuzzy approach for supplier selection } \\
\text { Intuitionistic group fuzzy information aggregation } \\
\text { Application of IT outsourcing supplier selection } \\
\text { A practical applicable approach for evaluating environmental } \\
\text { performance of suppliers consist of three steps } \\
\text { An integrated approach in a watch firm }\end{array}$ \\
\hline $\begin{array}{l}\text { Fuzzy ANP \& } \\
\text { Fuzzy TOPSIS \& } \\
\text { Fuzzy DEMATEL }\end{array}$ & $\begin{array}{l}\text { Buyukozkan and Cifci } \\
\text { [51] }\end{array}$ & A case study is proposed for green supplier evaluation \\
\hline Fuzzy ELECTRE & $\begin{array}{l}\text { Montazer et al. [52] } \\
\text { Sevkli [53] }\end{array}$ & $\begin{array}{l}\text { Fuzzy ELECTRE-III for vendor selection in oil industry } \\
\text { Comparing crisp and fuzzy models for supplier selection }\end{array}$ \\
\hline $\begin{array}{l}\text { Fuzzy DEMATEL } \\
\& \text { Fuzzy TOPSIS }\end{array}$ & Dalalah et al. [54] & A hybrid fuzzy model for group MCDM. \\
\hline Fuzzy VIKOR & $\begin{array}{l}\text { Chen and Wang [55] } \\
\text { Sanayei et al. [56] } \\
\text { Shemshadi et al. [57] }\end{array}$ & $\begin{array}{l}\text { Providing an efficient approach for selecting possible suppliers } \\
\text { A group decision making model based on linguistic variables } \\
\text { A group decision making model based on linguistic terms and entropy } \\
\text { weights. }\end{array}$ \\
\hline $\begin{array}{l}\text { Fuzzy } \\
\text { PROMETHEE }\end{array}$ & Chai et al. [58] & Extended superiority and inferiority ranking approach \\
\hline $\begin{array}{l}\text { R-BWM \& } \\
\text { R-MAIRCA } \\
\end{array}$ & Badi and Ballem [59] & $\begin{array}{l}\text { A rough BWM-MAIRCA model for supplier selection process in } \\
\text { pharmaceutical supplies. }\end{array}$ \\
\hline $\begin{array}{l}\text { A single valued } \\
\text { Neutrosophic } \\
\text { DEMATEL }\end{array}$ & Liu et al. [60] & $\begin{array}{l}\text { A new SVNN-DEMATEL multicriteria model of the selection of the } \\
\text { transport service provider. }\end{array}$ \\
\hline $\begin{array}{l}\text { FUCOM \& } \\
\text { Interval Rough } \\
\text { SAW }\end{array}$ & Stevic et al. [61] & $\begin{array}{l}\text { An integrated FUCOM-Interval Rough SAW model was developed to } \\
\text { rank and select suppliers. }\end{array}$ \\
\hline $\begin{array}{l}\text { Intuitionistic } \\
\text { fuzzy sets, } \\
\text { COPRAS } \\
\end{array}$ & Kumari \& Mishra [62] & Application of green supplier selection. \\
\hline $\begin{array}{l}\text { Picture fuzzy } \\
\text { exponential } \\
\text { Entropy \& } \\
\text { VIKOR } \\
\end{array}$ & Peng et al. [63] & $\begin{array}{l}\text { An integrated framework based on the picture fuzzy exponential } \\
\text { entropy, and VIKOR methods for sustainable supplier selection } \\
\text { process in chemical manufacturing sector. }\end{array}$ \\
\hline $\begin{array}{l}\text { Fuzzy } \\
\text { DEMATEL \& } \\
\text { Fuzzy ANP }\end{array}$ & $\begin{array}{l}\text { Phochanikorn and Tan } \\
\text { [64] }\end{array}$ & $\begin{array}{l}\text { An integrated approach is proposed for green supplier evaluation using } \\
\text { fuzzy DEMATEL and fuzzy ANP. }\end{array}$ \\
\hline $\begin{array}{l}\text { Pythagorean } \\
\text { Fuzzy sets \& } \\
\text { CODAS }\end{array}$ & Bolturk [65] & $\begin{array}{l}\text { An application based on Pythagorean fuzzy extension of CODAS } \\
\text { method for supplier selection. }\end{array}$ \\
\hline
\end{tabular}

There are several criteria that must be regarded in the supplier selection process. Table 2 shows some quantitative and qualitative criteria for supplier selection. 
Table 2. Supplier selection criteria according to some authors

\begin{tabular}{|c|c|c|c|c|c|c|c|c|c|c|c|c|c|}
\hline \multirow[b]{2}{*}{ Criteria } & \multicolumn{13}{|l|}{ Author(s) } \\
\hline & $\begin{array}{l}\text { Junior } \\
\text { et al. } \\
{[66]}\end{array}$ & $\begin{array}{l}\text { Dargi et } \\
\text { al. [67] }\end{array}$ & $\begin{array}{l}\text { Razaei } \\
\text { vd. [68] }\end{array}$ & Kar [69] & $\begin{array}{l}\text { Chen\& } \\
\text { Wu [70] }\end{array}$ & $\begin{array}{l}\text { Rajesh } \\
\& \\
\text { Malliga } \\
{[71]} \\
\end{array}$ & $\begin{array}{l}\text { Kannan } \\
\text { et al. } \\
{[38]}\end{array}$ & $\begin{array}{l}\text { Bruno } \\
\text { et al. } \\
{[72]}\end{array}$ & Lin [73] & $\begin{array}{l}\text { Asamoa } \\
h \text { et al } \\
{[74]}\end{array}$ & $\begin{array}{l}\text { Mafakh } \\
\text { eri et al } \\
\text { [75] }\end{array}$ & $\begin{array}{l}\text { Kilincci } \\
\& \text { Onal } \\
{[34]}\end{array}$ & $\begin{array}{l}\text { Khoras } \\
\text { ani \& } \\
\text { Bafruei } \\
{[76]}\end{array}$ \\
\hline Cost/price & * & $*$ & $*$ & * & * & $*$ & * & & * & $*$ & * & * & $*$ \\
\hline Quality & $*$ & $*$ & $*$ & & $*$ & $*$ & $*$ & * & $*$ & $*$ & $*$ & $*$ & $*$ \\
\hline Technical Skill & & $*$ & & & & & & & $*$ & & & $*$ & * \\
\hline Delivery & $*$ & $*$ & * & $*$ & $*$ & $*$ & $*$ & & $*$ & & * & $*$ & \\
\hline Capacity & & $*$ & & $*$ & & & & & & * & & & \\
\hline $\begin{array}{l}\text { Environmental } \\
\text { performance }\end{array}$ & & & & & & & $*$ & & & & * & & \\
\hline Relationship & $*$ & & & & & & & & & & & & * \\
\hline Reputation & $*$ & $*$ & & & & & & & & & & & \\
\hline $\begin{array}{l}\text { Financial } \\
\text { situation }\end{array}$ & * & & * & $*$ & & & & * & & & & & \\
\hline Location & & & & & & & & & & & & $*$ & \\
\hline Innovation & & & & & & & & $*$ & & & & & \\
\hline Warranty & & & & & & & & & & & & & \\
\hline $\begin{array}{l}\text { Technological } \\
\text { capability } \\
\text { Social factors }\end{array}$ & & & $*$ & $*$ & $*$ & & $*$ & & & & & & \\
\hline Service & & & & & * & & & * & & & & * & $*$ \\
\hline Flexibility & & & & & & & & & & & & & \\
\hline Reliability & & & & & & & & & & & & & \\
\hline & $\begin{array}{l}\text { Chamo } \\
\text { drakas } \\
\text { et al. } \\
{[31]}\end{array}$ & $\begin{array}{l}\text { Sen et } \\
\text { al. [32] }\end{array}$ & $\begin{array}{l}\text { Amid et } \\
\text { al. [33] }\end{array}$ & $\begin{array}{l}\text { Razmi } \\
\text { et al. } \\
{[42]}\end{array}$ & $\begin{array}{l}\text { Buyuko } \\
\text { zkan \& } \\
\text { Cifci } \\
\text { [44] }\end{array}$ & $\begin{array}{l}\text { Boran et } \\
\text { al. [47] }\end{array}$ & $\begin{array}{l}\text { Buyuko } \\
\text { zkan \& } \\
\text { Ersoy } \\
{[48]}\end{array}$ & $\begin{array}{l}\text { Aksoy } \\
\& \\
\text { Ozturk } \\
{[77]} \\
\end{array}$ & $\begin{array}{l}\text { Liao \& } \\
\text { Kao } \\
{[50]}\end{array}$ & $\begin{array}{l}\text { Wei et } \\
\text { al. [78] }\end{array}$ & $\begin{array}{l}\text { Jolai et } \\
\text { al. [79] }\end{array}$ & $\begin{array}{l}\text { Kuo et } \\
\text { al. [80] }\end{array}$ & $\begin{array}{l}\text { Mendo } \\
\text { za et al. } \\
{[81]}\end{array}$ \\
\hline Cost/price & $*$ & * & * & * & $*$ & * & & $*$ & 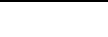 & * & * & * & * \\
\hline Quality & * & * & * & * & * & * & * & * & * & * & * & * & * \\
\hline Technical Skill & & & & & & & & & & & & & \\
\hline Delivery & $*$ & & & & * & * & & * & * & & * & * & * \\
\hline Capacity & & & & & & & & & & & & & \\
\hline $\begin{array}{l}\text { Environmental } \\
\text { performance }\end{array}$ & & & & & & & & & & & & * & \\
\hline Relationship & & & & & & * & $*$ & & $*$ & & $*$ & & \\
\hline Reputation & & & & * & & & * & & & & & & \\
\hline $\begin{array}{l}\text { Financial } \\
\text { situation }\end{array}$ & & & & $*$ & & & & & & & & & \\
\hline Location & & & & & & & & * & & & & & \\
\hline Innovation & & & & & & & & & & & & & \\
\hline Warranty & & & & & & & & & * & & & & \\
\hline $\begin{array}{l}\text { Technological } \\
\text { capability }\end{array}$ & & & & & & & * & & & & * & & \\
\hline Social factors & & & & & & & & & & & & * & \\
\hline Service & & * & * & & & & * & & & * & & * & $*$ \\
\hline Flexibility & & & & & * & & & & & & & & $*$ \\
\hline Reliability & & * & & & & & & & & * & & & \\
\hline
\end{tabular}

\section{Research Methodology}

This section presents theoretical background of Interval Type-2, IT2F-AHP and COPRAS -G methods.

\subsection{Interval Type-2 Fuzzy Sets}

Type -1 fuzzy sets are unable to handle with uncertainties in "prototypical word", working on meaningless data display the ambiguity of type-1 fuzzy sets. The prototypical word means different things to different people. For example, if the value is assigned as 0.5 , the element belongs to 50 percent to type- 1 fuzzy set. The value of the membership degree can be varied from different people to people. A single membership value has revealed uncertainty [82]. However, difficulties of the aggregation of experts' opinions, noisy data from measurements activating revealed the vagueness in the concept of the type- 1 fuzzy sets Type 2 fuzzy sets are introduced by Zadeh 
[83] as an extension of the concept of the ordinary type-1 fuzzy sets. Type-2 fuzzy sets enable directly handle with uncertainties better than type-2 fuzzy sets.

Both of fuzzy sets are mapped to value between 0 and 1. All fuzzy sets are characterized by membership functions. Type-1 fuzzy sets have two-dimensional (2-D) membership function while, type-2 fuzzy sets have threedimensional (3-D) membership function. New membership function is called the footprint of uncertainty (FOU) that provide additional degree of freedom to capture more information. On the other hand, type-2 fuzzy sets are difficult to understand and apply due to computational difficulties and excessive mathematical formulas. Interval type 2 fuzzy sets developed to reduce the computational complexity of the concept of type-1 fuzzy sets [84]. The mathematical formulations of interval type 2 fuzzy sets are given following:

Definition 1: A type-2 fuzzy set is characterized by a type-2 membership function, $\mathrm{X}$ can be reprented by a type-2 membership function $\mu_{\text {for }}(\mathrm{x}, \mathrm{u})=1$ where $\mathrm{x}$ is the main element in the domain $\mathrm{X}$, given as Eq.(1). [85]

$$
\tilde{\tilde{A}}=\left\{(x, u), \mu_{\tilde{A}}(x, u) \mid \forall x \in X, 0 \leq \mu_{\tilde{A}}(x, u) \leq 1\right\}
$$

where $\forall u \in J_{X} \subseteq[0,1]$. The type-2 fuzzy set can be reprented as in Eq.

$$
\tilde{\tilde{A}}=\int_{x \in X} \int_{u \in J_{X}} \mu_{\tilde{A}}(x, u) /(x, u)
$$

where $u$ is the secondary variable in domain $J_{X}$ at each $x \in X . J_{X}$ is called the primary membership of $x$, and the secondary membership grades of $X^{6}$ all equal to $1, J_{X} \subseteq[0,1]$ and $\iint$ denote union over all admissible $x$ and $u$.

Definition 2. An interval type-2 fuzzy set $\AA^{\varepsilon}$ is a special case of general type-2 fuzzy sets where all the secondary membership functions of $\sim A$ are equal to 1 . If all $\mu_{\text {姶 }}(\mathrm{x}, \mathrm{u})=1$, then ${ }^{\prime} \mathrm{E}_{\text {is }}$ called an interval type-2 fuzzy sets that is the special case of a type-2 fuzzy set, represent as Eq.3 [82,85].

$$
\tilde{\tilde{A}}=\int_{x \in X} \int_{u \in J_{x}} 1 /(x, u)
$$

Definition 3. The upper membership function and lower membership function of an interval type-2 fuzzy set are type- 1 membership functions, respectively. Figure 1 shows a trapezoidal interval type- 2 fuzzy set in this study $[82,85]$.

$$
\AA_{i}^{O}=\left(A_{i}^{b}, \AA_{i}^{b}\right)=\left(\begin{array}{l}
\left(a_{i 1}^{U}, a_{i 2}^{U}, a_{i 3}^{U}, a_{i 4}^{U} ; H_{1}\left(\tilde{A}_{i}^{U}\right), H_{2}\left(\tilde{A}_{i}^{U}\right)\right), \\
\left(a_{i 1}^{L}, a_{i 2}^{L}, a_{i 3}^{L}, a_{i 4}^{L} ; H_{1}\left(\tilde{A}_{i}^{L}\right), H_{2}\left(\tilde{A}_{i}^{L}\right)\right)
\end{array}\right)
$$

where $A_{i}^{6 \sigma}$ and $\AA_{i}^{b}$ are type 1 fuzzy sets, $a_{i 1}^{U}, a_{i 2}^{U}, a_{i 3}^{U}, a_{i 4}^{U}, a_{i 1}^{L}, a_{i 2}^{L}, a_{i 3}^{L}, a_{i 4}^{L}$ are the references points of the interval type-2 fuzzy $A, H_{j}\left(\AA_{i}^{b}\right)$ indicates the membership value of the element $a_{i(j+1)}^{U}$ in the upper trapezoidal membership function $\AA_{i}^{b} ; 1 \leq j \leq 2, H_{j}\left(\AA_{i}^{b}\right)$ shows the membership value of the element $a_{i(j+1)}^{U}$ in the upper trapezoidal membership function $\AA_{i}^{\varnothing 6}$; and $1 \leq j \leq 2, H_{j}\left(\AA_{i}^{6}\right), H_{j}\left(\AA_{i}^{b}\right) \in[0,1], 1 \leq i \leq n$.

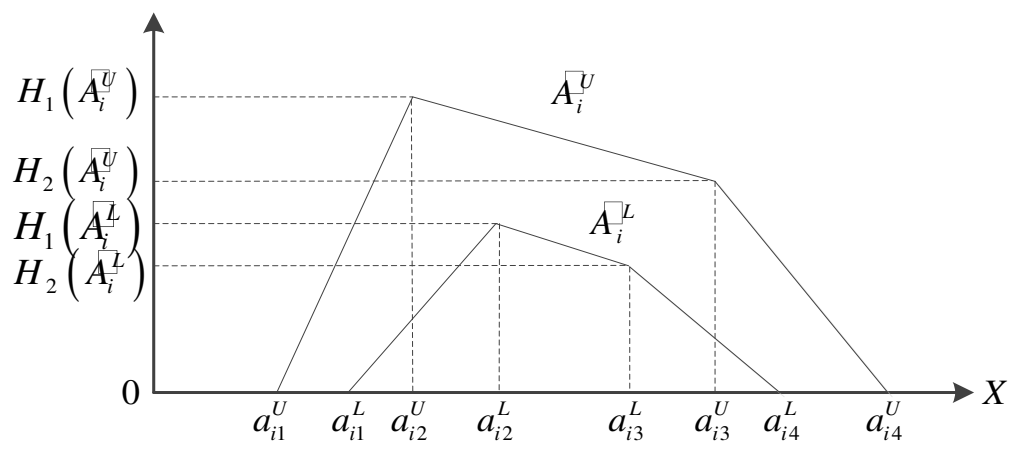

Fig. 1 The membership functions of the interval type-2 fuzzy set 
Some arithmetic operations with interval type-2 fuzzy numbers are shown in the following definitions $[86,87]$. Definition 4. The addition operation between two trapezoidal interval type-2 fuzzy sets is defined as in Eq. (5)

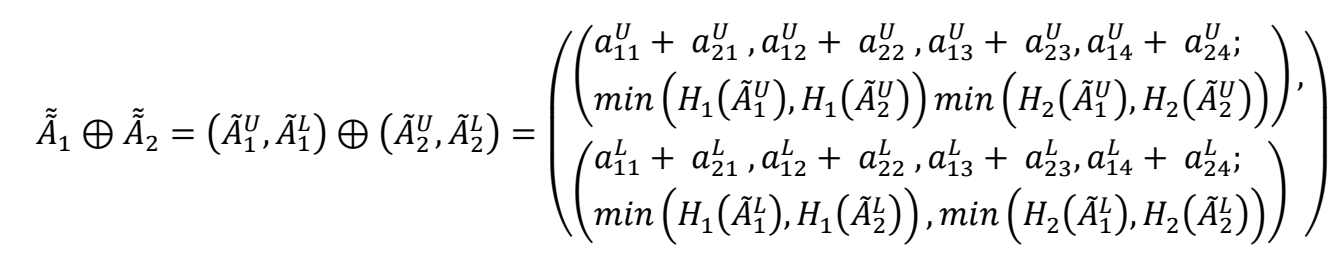

Definition 5. The subtraction operation between the trapezoidal interval type-2 fuzzy sets is defined as follows

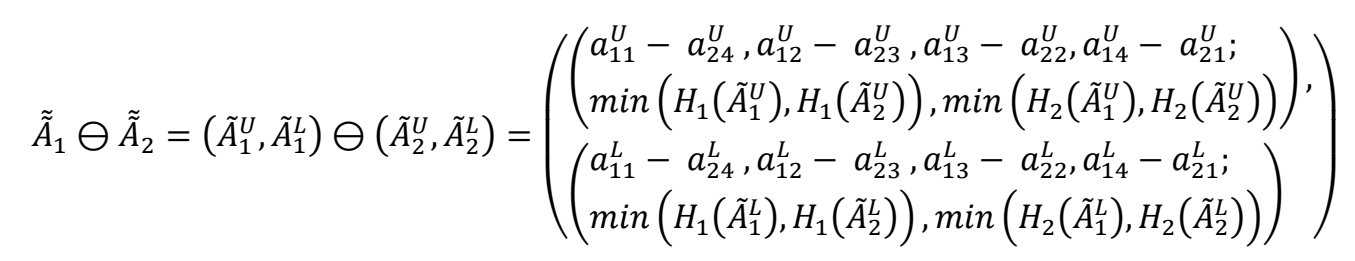

Definition 6. The multiplication operation between the trapezoidal interval type-2 fuzzy sets is represented as follows.

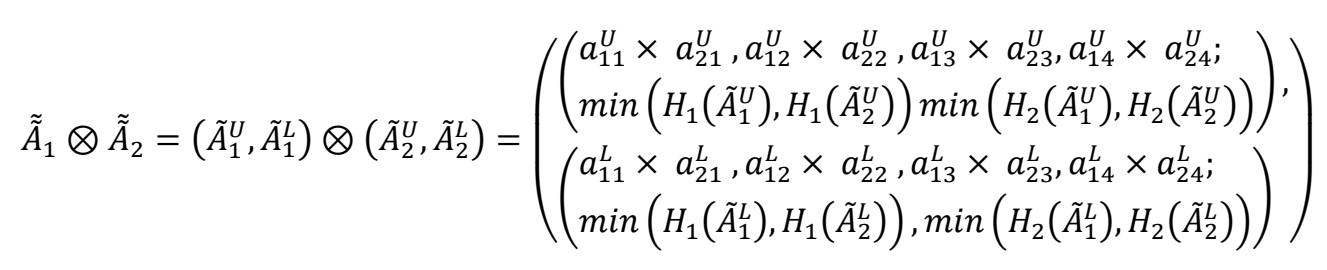

Definition 7. Some arithmetic operations between the trapezoidal interval type-2 fuzzy set and the crisp value $k$ are defined as follows.

$$
\begin{gathered}
k \times \tilde{A}_{1}=\left(\begin{array}{c}
\left(k \times a_{11}^{U}, k \times a_{12}^{U}, k \times a_{13}^{U}, k \times a_{14}^{U} ; H_{1}\left(\tilde{A}_{1}^{U}\right), H_{2}\left(\tilde{A}_{1}^{U}\right)\right), \\
\left(k \times a_{11}^{L}, k \times a_{12}^{L}, k \times a_{13}^{L}, k \times a_{14}^{L} ; H_{1}\left(\tilde{A}_{1}^{L}\right), H_{2}\left(\tilde{A}_{1}^{L}\right)\right)
\end{array}\right) \\
\frac{\tilde{A}_{1}}{k}=\left(\begin{array}{c}
\left(\frac{1}{k} \times a_{11}^{U}, \frac{1}{k} \times a_{12}^{U}, \frac{1}{k} \times a_{13}^{U}, \frac{1}{k} \times a_{14}^{U} ; H_{1}\left(\tilde{A}_{1}^{U}\right), H_{2}\left(\tilde{A}_{1}^{U}\right)\right), \\
\left(\frac{1}{k} \times a_{11}^{L}, \frac{1}{k} \times a_{12}^{L}, \frac{1}{k} \times a_{13}^{L}, \frac{1}{k} \times a_{14}^{L} ; H_{1}\left(\tilde{A}_{1}^{L}\right), H_{2}\left(\tilde{A}_{1}^{L}\right)\right)
\end{array}\right)
\end{gathered}
$$

Definition 8. The ranking value $\operatorname{Rank}\left(\tilde{\tilde{A}}_{i}\right)$ of the trapezoidal interval type-2 fuzzy set $A_{i}^{8}$ is defined as following equation.

$$
\begin{aligned}
& \operatorname{Rank}\left(\tilde{A}_{i}\right)=M_{1}\left(\tilde{A}_{i}^{U}\right)+M_{1}\left(\tilde{A}_{i}^{L}\right)+M_{2}\left(\tilde{A}_{i}^{U}\right)+M_{2}\left(\tilde{A}_{i}^{L}\right)+M_{3}\left(\tilde{A}_{i}^{U}\right) \\
& +M_{3}\left(\tilde{A}_{i}^{L}\right)-\frac{1}{4}\left(S_{1}\left(\tilde{A}_{i}^{U}\right)+S_{1}\left(\tilde{A}_{i}^{L}\right)+S_{2}\left(\tilde{A}_{i}^{U}\right)+S_{2}\left(\tilde{A}_{i}^{L}\right)\right) \\
& -\frac{1}{4}\left(S_{3}\left(\tilde{A}_{i}^{U}\right)+S_{3}\left(\tilde{A}_{i}^{L}\right)+S_{4}\left(\tilde{A}_{i}^{U}\right)+S_{4}\left(\tilde{A}_{i}^{L}\right)\right)+H_{1}\left(\tilde{A}_{i}^{U}\right)+H_{1}\left(\tilde{A}_{i}^{L}\right)+H_{2}\left(\tilde{A}_{i}^{U}\right)+H_{2}\left(\tilde{A}_{i}^{L}\right)
\end{aligned}
$$

where $M_{p}\left(\tilde{A}_{i}^{j}\right)$ denotes the average of the elements $a_{i p}^{j}$ and $a_{i(p+1)}^{j}$,

$$
M_{p}\left(\tilde{A}_{i}^{j}\right)=\left(a_{i p}^{j}+a_{i(p+1)}^{j}\right) / 2,1 \leq p \leq 3
$$

denotes the standard deviation of the elements $a_{i 1}^{j}, a_{i 2}^{j}, a_{i 3}^{j}, a_{i 4}^{j}$

$$
S_{q}\left(\tilde{A}_{i}^{j}\right)=\sqrt{\frac{1}{2} \sum_{k=q}^{q+1}\left(a_{i k}^{j}-\frac{1}{2} \sum_{k=q}^{q+1} a_{i k}^{j}\right)^{2}}, 1 \leq q \leq 3
$$

$S_{4}\left(\tilde{A}_{i}^{j}\right)$ denotes the standard deviation of the elements $a_{i 1}^{j}, a_{i 2}^{j}, a_{i 3}^{j}, a_{i 4}^{j}$ 


$$
S_{4}\left(\AA_{i}^{\phi}\right)=\sqrt{\frac{1}{4} \sum_{k=1}^{4}\left(a_{i k}^{j}-\frac{1}{4} \sum_{k=1}^{4} a_{i k}^{j}\right)^{2}}
$$

$H_{p}\left(\tilde{A}_{i}^{j}\right)$ denotes the membership value of the element $a_{i(p+1)}^{j}$ in the trapezoidal membership function $\tilde{A}_{i}^{j}, 1 \leq p \leq$ $2, j \in\{U, L\}$ and $1 \leq i \leq n$.

\subsection{Interval Type -2 Fuzzy AHP}

AHP is one of MCDM method that was originally introduced by Saaty [88]. AHP is a qualitative method that consider processing the subjective and objective preferences of an individual or a group in decision making. Fundamentally, the AHP has a conceptual hierarchical structure that consists of goal or alternatives, main criteria and sub-criteria. This method aims to find relative priority and weight of criteria and alternatives based on decision makers' judgements. Due to its hierarchical structure, AHP is the one of the most powerful and effective method among MCDM to deal with complex and uncertain real-life problems that involve qualitative and quantitative criteria [89]

Most real-life world problems are uncertain and ill-defined. Decision maker has difficulty to select what is the best decision. From this point of view, Fuzzy set theory, as established by Zadeh is widely used to handle imprecise, vague, uncertain data, in the real-life environments [90]. For making a better decision, linguistic terms can be developed as quantitative data, this type of data set is then refined by the evaluation methods of fuzzy set theory. The AHP method consists of the experiences and judgements of decision-makers which are usually made under uncertain an imprecise evaluation of quantitative or qualitative criteria. Therefore, traditional AHP may be quite tendentious and disadvantageous by cause of uncertainty associated with inconsistent error in comparison matrices. Experts prefer to express with verbally of their experiences and judgments in pairwise comparisons. This linguistic expression will be more accurate than fixed value judgement [91].

They are many types of fuzzy AHP applications which use different linguistic terms in the literature review. To improve the confidence of decision makers for AHP method, fuzzy AHP is developed by van Laarhoven and Pedrycz to reduce the judgmental subjectivity and ambiguity in pairwise comparisons [92]. Buckley (1985) extended fuzzy AHP method integrating the geometric mean method with triangular fuzzy numbers [93]. Geometric mean method helps to calculate fuzzy weights developed fuzzy AHP with extent analysis method to reduce computational difficulties [94].

The IT2FS theory, the upper and lower membership functions would allow some degree of freedom to point out the high-level imprecise and vagueness of the real-life environments. In order to eliminate uncertainty and vagueness, fuzzy AHP is extended as Interval type-2 fuzzy AHP. The steps of Interval Type-2 Fuzzy AHP method are defined in the following [12]:

Step 1: Define the problem goal, criteria, and alternatives

This step is applied like the type-1 Fuzzy AHP. The main criteria, sub-criteria, alternatives, and goal are determined by experts using linguistic variables.

Step 2: Construct fuzzy pairwise comparisons matrices

Pairwise comparison matrices for alternatives, criteria and sub criteria are evaluated using linguistic terms which are represented by fuzzy triangular numbers. Interval type -2 fuzzy scales used in this study are presented in Table 3.

Table 3. Definition Interval Type-2 Fuzzy Scale of the Linguistic Variables

\begin{tabular}{ll}
\hline Linguistic Variables & Trapezoidal interval fuzzy scales \\
\hline Equally important (E) & $(1,1,1,1 ; 1,1)(1,1,1,1 ; 1,1)$ \\
Weakly important (WI) & $(1,2,4,5 ; 1,1)(1.2,2.2,3.8,4.8 ; 0.8,0.8)$ \\
Strongly important (S) & $(3,4,6,7 ; 1,1)(3.2,4.2,5.8,6.8 ; 0.8,0.8)$ \\
Very strongly important (VS) & $(5,6,8,9 ; 1,1)(5.2,6.2,7.8,8.8 ; 0.8,0.8)$ \\
Absolutely important (AS) & $(7,8,9,9 ; 1,1)(7.2,8.2,8.8,9 ; 0.8,0.8)$ \\
\hline
\end{tabular}

The comparison value $\tilde{\tilde{a}}_{i j}$ defined as triangular fuzzy numbers, with in the type- 2 interval fuzzy sets $(\widetilde{\widetilde{M}})$ as represent in the following:

where

$$
\widetilde{\widetilde{M}}=\left(\begin{array}{cccc}
1 & \tilde{a}_{12} & \cdots & \tilde{\tilde{a}}_{1 n} \\
\tilde{\tilde{a}}_{21} & 1 & \cdots & \tilde{\tilde{a}}_{2 n} \\
\vdots & \vdots & \ddots & \vdots \\
\tilde{\tilde{a}}_{n 1} & \tilde{\tilde{a}}_{n 2} & \cdots & 1
\end{array}\right)=\left(\begin{array}{cccc}
1 & \tilde{\tilde{a}}_{12} & \cdots & \tilde{\tilde{a}}_{1 n} \\
1 / \tilde{\tilde{a}}_{12} & 1 & \cdots & \tilde{\tilde{a}}_{2 n} \\
\vdots & \vdots & \ddots & \vdots \\
1 / \tilde{\tilde{a}}_{1 n} & 1 / \tilde{\tilde{a}}_{2 n} & \cdots & 1
\end{array}\right)
$$




$$
1 / \tilde{\tilde{a}}_{i j}=\left(\left(\frac{1}{a_{i j 4}^{U}}, \frac{1}{a_{i j 3}^{U}}, \frac{1}{a_{i j 2}^{U}}, \frac{1}{a_{i j 1}^{U}} ; H_{1}\left(\tilde{\tilde{a}}_{i j}^{U}\right), H_{2}\left(\tilde{\tilde{a}}_{i j}^{U}\right)\right),\left(\frac{1}{a_{i j 4}^{L}}, \frac{1}{a_{i j 3}^{L}}, \frac{1}{a_{i j 2}^{L}}, \frac{1}{a_{i j 1}^{L}} ; H_{1}\left(\tilde{\tilde{a}}_{i j}^{L}\right), H_{2}\left(\tilde{\tilde{a}}_{i j}^{L}\right)\right)\right)
$$

Step 3: Examine the Consistency Ratio of each pairwise comparison matrix

The calculation of the consistency of pairwise matrices is like traditional AHP. If the result of the pairwise comparison matrix is consistent, then the interval type-2 pairwise comparison matrix is also consistent. The value of the consistency ratio (CR) is equal or smaller than 0.1 , the consistency is acceptable. If the consistency ratio is greater than 0.1, experts should revise their judgements again.

Step 4: Calculate the Geometric Means

Geometric mean technique is used to aggregate the expert's judgement. The geometric mean of each row is computed by using Eq. (16) and then the fuzzy weights are computed by normalization.

$$
\tilde{\tilde{r}}_{i}=\left(\tilde{\tilde{a}}_{i 1} \otimes \tilde{\tilde{a}}_{i 2} \otimes \cdots \otimes \tilde{\tilde{a}}_{i n}\right)^{1 / n}
$$

Where

$$
\sqrt[n]{\tilde{\tilde{a}}_{i 1}}=\left(\left(\sqrt[n]{a_{i j 1}^{U}}, \sqrt[n]{a_{i j 2}^{U},}, \sqrt[n]{a_{i j 3}^{U}}, \sqrt[n]{a_{i j 4}^{U}} ; H_{1}\left(\tilde{a}_{i j}^{U}\right), H_{2}\left(\tilde{\tilde{a}}_{i j}^{U}\right)\right),\left(\sqrt[n]{a_{i j 1}^{L},}, \sqrt[n]{a_{i j 2}^{L},}, \sqrt[n]{a_{i j 3}^{L}}, \sqrt[n]{a_{i j 4}^{L}} ; H_{1}\left(\tilde{\tilde{a}}_{i j}^{L}\right), H_{2}\left(\tilde{\tilde{a}}_{i j}^{L}\right)\right)\right)
$$

Step 5: Find the fuzzy weights of each criterion is calculated as follows.

$$
\widetilde{\widetilde{w}}_{i}=\tilde{\tilde{r}}_{i} \otimes\left(\tilde{\tilde{r}}_{1} \oplus \tilde{\tilde{r}}_{2} \oplus \cdots \oplus \tilde{\tilde{r}}_{n}\right)^{-1}
$$

\section{Step 6: Defuzzify the type-2 interval fuzzy sets to calculate the weights of the criteria}

Kahraman et al. offered a method for Trapezoidal type-2 fuzzy sets were offered by modifying the Best Nonfuzzy Performance (BNP) value for defuzzifying and ranking interval type-2 fuzzy sets show as following [12]: Defuzzified $\left(\widetilde{\widetilde{w}}_{i}\right)=$

$$
\frac{\frac{\left(u_{U}-l_{U}\right)+\left(\beta_{U} * m_{1 U}-l_{U}\right)+\left(\alpha_{U} * m_{2 U}-l_{U}\right)}{4}+l_{U}+\left[\frac{\left(u_{L}-l_{L}\right)+\left(\beta_{L} * m_{1 L}-l_{L}\right)+\left(\alpha_{L} * m_{2 L}-l_{L}\right)}{4}+l_{L}\right]}{2}
$$

Step 7: Normalize the crisp weights of each criteria

$$
w_{i}=\operatorname{Defuzzified}\left(\widetilde{\widetilde{w}}_{i}\right) / \sum_{i=1}^{n} \text { Defuzzified }\left(\widetilde{\widetilde{w}}_{i}\right), \quad \mathrm{i}=1, \ldots, n
$$

\subsection{COPRAS -G Method}

Multi criteria decision making analysis are related to the situation in which a decision maker has to choose among several alternatives by considering a particular set of criteria. In real applications, the most of criteria values cannot be denoted by exact numbers. Therefore, multi attributed decision-making problems need to be functioned with fuzzy values or with values in some intervals.

Zavadskas et.al presented the main ideas of COPRAS-G (Complex Proportional Assessment method with Grey interval numbers) method. The COPRAS-G method with attribute values expressed in intervals is based on the real conditions of decision-making and applications of the Grey systems theory [95]. This method uses a ranking procedure of the alternatives based on their significance and utility degrees. The procedure of the COPRAS-G method consists in the following steps [16, 95, 96]:

Step 1: Selecting the set of criteria, describing the alternatives.

Step 2: Forming the grey decision-making matrix $\otimes X$ Eq. (21)

$$
\otimes X=\left[\begin{array}{cccc}
\otimes x_{11} & \cdots & \cdots & \otimes x_{1 m} \\
\otimes x_{21} & \cdots & \cdots & \otimes x_{2 m} \\
\vdots & \cdots & \ddots & \vdots \\
\otimes x_{n 1} & \cdots & \cdots & \otimes x_{n m}
\end{array}\right]=\left[\begin{array}{cccc}
\underline{x}_{11} ; \bar{x}_{11} & \cdots & \cdots & \underline{x}_{1 m} ; \bar{x}_{1 m} \\
\underline{x}_{21} ; \bar{x}_{21} & \cdots & \cdots & \underline{x}_{2 m} ; \bar{x}_{2 m} \\
\vdots & \cdots & \ddots & \vdots \\
\underline{x}_{n 1} ; \bar{x}_{n 1} & \cdots & \cdots & \underline{x}_{n m} ; \bar{x}_{n m}
\end{array}\right] ; j=1,2, \ldots, n, i=1,2, \ldots, m
$$

Where $\mathrm{m}$ is the number of criteria and $\mathrm{n}$ is the number of alternatives. $\otimes x_{j i}$ is determined by $\underline{x}_{j i}$ (the smallest value, the lower limit) and $\bar{x}_{j i}$ (the biggest value, the upper limit) and it shows the score of alternative $\mathrm{j}$ in terms of criterion i. The linguistic variables and their corresponding grey numbers to evaluate alternatives are shown Table 4. 
Table 4. Linguistic variables and grey numbers [97]

\begin{tabular}{lc}
\hline Linguistic variables & Grey numbers \\
\hline Very poor (VP) & {$[0,1]$} \\
Poor (P) & {$[1,3]$} \\
Medium Poor (MP) & {$[3,4]$} \\
Fair (F) & {$[4,5]$} \\
Medium Good (MG) & {$[5,6]$} \\
Good (G) & {$[6,9]$} \\
Very Good (VG) & {$[9,10]$} \\
\hline
\end{tabular}

Step 3: Normalizing the grey decision-making matrix $(\otimes \tilde{X})$. The normalized grey decision-making matrix is calculated by Eq. (22).

$$
\underline{\tilde{x}}_{j i}=\frac{\underline{x}_{j i}}{\frac{1}{2}\left(\sum_{j=1}^{n} \underline{x}_{j i}+\sum_{j=1}^{n} \bar{x}_{j i}\right)}, \tilde{\bar{x}}_{j i}=\frac{\bar{x}_{j i}}{\frac{1}{2}\left(\sum_{j=1}^{n} \underline{x}_{j i}+\sum_{j=1}^{n} \bar{x}_{j i}\right)} ; j=1,2, \ldots, n, i=1,2, \ldots, m
$$

The normalized grey decision matrix $\otimes \tilde{X}$ is developed by Eq. (23):

$$
\otimes \tilde{X}=\left[\begin{array}{cccc}
\tilde{x}_{11} ; \tilde{\bar{x}}_{11} & \tilde{x}_{12} ; \tilde{\bar{x}}_{12} & \cdots & \underline{x}_{1 m} ; \tilde{\bar{x}}_{1 m} \\
\tilde{\tilde{x}}_{21} ; \tilde{\overline{\bar{x}}}_{21} & \underline{\tilde{x}}_{22} ; \tilde{\bar{x}}_{22} & \cdots & \underline{\tilde{x}}_{2 m} ; \tilde{\bar{x}}_{2 m} \\
\vdots & \vdots & \ddots & \vdots \\
\tilde{x}_{n 1} ; \tilde{\overline{\bar{x}}}_{n 1} & \underline{\tilde{x}}_{n 2} ; \tilde{\bar{x}}_{n 2} & \cdots & \underline{\tilde{x}}_{n m} ; \tilde{\bar{x}}_{n m}
\end{array}\right]
$$

Step 4: Determining weights of the criteria $\left(w_{i}\right)$. In this step, the relative importance weight of each criteria, which is calculated with Interval Type-2 Fuzzy AHP method in this paper is obtained.

Step 5: Calculating the weighted normalized grey decision-making matrix $(\otimes \hat{X})$. The weighted normalized grey decision matrix values calculated by Eq. (24) through multiplying the normalized decision matrix by the weights vector of criteria.

$\otimes \hat{x}_{j i}=\otimes \tilde{x}_{j i} \cdot w_{i} ;$ or $\underline{\hat{x}}_{j i}=\underline{\tilde{x}}_{j i} \cdot w_{i}$ and $\overline{\hat{x}}_{j i}=\overline{\tilde{x}}_{j i} \cdot w_{i}$

The weighted normalized grey decision matrix is formed as Eq. (25):

$$
\otimes \hat{X}=\left[\begin{array}{cccc}
\otimes \hat{x}_{11} & \bigotimes \hat{x}_{12} & \cdots & \otimes \hat{x}_{1 m} \\
\bigotimes \hat{x}_{21} & \bigotimes \hat{x}_{22} & \cdots & \otimes \hat{x}_{2 m} \\
\vdots & \cdots & \ddots & \vdots \\
\otimes \hat{x}_{n 1} & \bigotimes \hat{x}_{n 2} & \cdots & \bigotimes \hat{x}_{n m}
\end{array}\right]=\left[\begin{array}{cccc}
\underline{x}_{11} ; \overline{\hat{x}}_{11} & \hat{x}_{12} ; \overline{\hat{x}}_{12} & \cdots & \underline{\hat{x}}_{1 m} ; \overline{\hat{x}}_{1 m} \\
\hat{x}_{21} ; \overline{\hat{x}}_{21} & \underline{\hat{x}}_{22} ; \overline{\hat{x}}_{22} & \cdots & \underline{\hat{x}}_{2 m} ; \overline{\hat{x}}_{2 m} \\
\vdots & \vdots & \ddots & \vdots \\
\hat{x}_{n 1} ; \overline{\hat{x}}_{n 1} & \underline{\hat{x}}_{n 2} ; \overline{\hat{x}}_{n 2} & \cdots & \underline{\hat{x}}_{n m} ; \overline{\hat{x}}_{n m}
\end{array}\right]
$$

Step 6: Obtaining the relative importance of each alternative by obtaining the summation of $P_{j}$ (whose larger values are preferable) and the summation of $R_{j}$ (whose smaller values are preferable) for each criterion values using Eqs. (26) and (27):

$$
\begin{gathered}
P_{j}=\frac{1}{2} \sum_{i=1}^{k}\left(\underline{\hat{x}}_{j i}+\overline{\hat{x}}_{j i}\right) \quad j=1,2, \ldots, n ; i=1,2, \ldots, k \\
R_{j}=\frac{1}{2} \sum_{i=k+1}^{m}\left(\underline{\hat{x}}_{j i}+\overline{\hat{x}}_{j i}\right) \quad j=1,2, \ldots, n ; i=k+1, k+2, \ldots, m
\end{gathered}
$$

Step 7: Determining the minimal value of $R_{j}$ as follows Eq. (28):

$$
R_{j}=\min _{j} R_{j} \quad j=1,2, \ldots, n
$$

Step 8: Obtaining the relative importance of each alternative as follows Eq. (29):

$$
Q_{j}=P_{j}+\frac{\sum_{R_{j}}^{n} \sum_{j=1}^{n} \frac{1}{R_{j}}}{R_{j}} \quad j=1,2, \ldots, n
$$

Step 9: Calculating the utility degree of each alternative $\left(N_{j}\right)$ by determining the best alternative $K$ as follows Eq. (30):

$$
K=\max _{j} Q_{j} \quad j=1,2, \ldots, n
$$

Utility degree of each alternative allows of a comparison with the ideal alternative. The value of the utility degrees ranges from $0 \%$ (for the worst alternative) to $100 \%$ (for the best alternative) is obtained by Eq. (31):

$$
N_{j}=\frac{Q_{j}}{Q_{\max }} \times 100 \% \quad j=1,2, \ldots, n
$$




\section{Case Study: Supplier selection for textile manufacturer}

An illustrative example is provided to present the integrated IT2F-AHP and COPRAS-G approach-based framework for textile supplier selection with respect to Industry 4.0 technologies and processes. The weights of key criteria are determined by IT2F-AHP and then the most suitable alternative is selected by COPRAS-G approach using the evaluated weights.

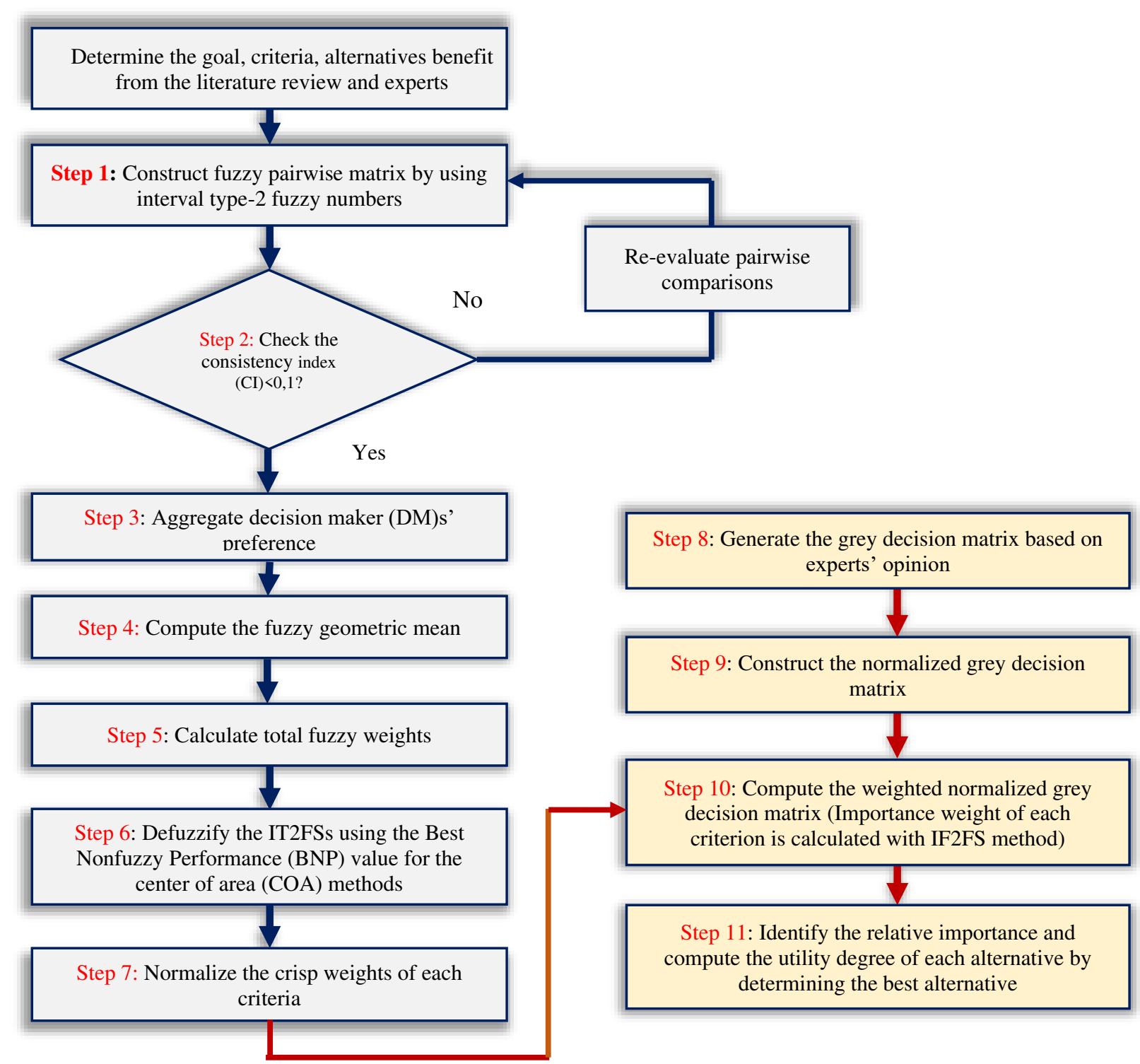

Fig.2. Systematic steps of the proposed methodology

\subsection{Problem Statement}

In this section, a numerical application of IT2F-AHP and COPRAS-G in a real-life study is presented. The case study is from a high-performance technical textile manufacturer (ABC) which has two factories in Turkey and one in Hungary. The management of this company try to adopt the implementation of Industry 4.0 throughout their manufacturing and supply chain processes. In order to maintain fast, flexible, and efficient production operations, supplier integration in the context of Industry 4.0 become more important for ABC company.

$\mathrm{ABC}$ manufacturer wants to select the most appropriate supplier based on industry 4.0 initiatives for purchasing the raw materials of high-performance textile products. They are five experts who are the company's team working in the sales and production departments and four candidate suppliers. The experts were contacted through an email and phones requesting their participation and judgements.

Four potential suppliers $\left(S_{1}, S_{2}, S_{3}, S_{4}\right)$ have been identified for the further evaluation (COPRAS-G). Ten evaluation criteria for supplier selection are determined with respect to literature studies and the comments of the decision-making team. All evaluation criteria of suppliers are discussed by some researchers and experts. Literature review of traditional supplier criteria are: cost and quality $[31,32,33,34,42,44,46,50,66,67,68,70$, 
$71,72,73,74,75,76,77,78,79,80,81]$, delivery $[31,34,38,42,46,50,66,67,68,69,70,71,73,75,79,80$, 81], capacity [67, 69,74]. This study differentiates from the existing studies by consider the components of Industry 4.0 that leads to great innovations in supplier assessment. In this study, "Smart warehouse and shelving system", "Intelligent Transportation System such as GPS, RFID and dynamic sensors", "Employee training on Industry 4.0", "Use of autonomous machine", "Internet of Things (IoT) Implementation", "Big data and Cloud computing" criteria are used for the first time in the supplier selection literature. All supplier selection criteria are identified and detailed as follows:

$\checkmark$ Cost / Price (C1): The final cost to purchase a unit of raw or semi-finished textile products.

$\checkmark$ Quality (C2): The performance of materials purchased to meet the requirements and expectations in service or product that were committed to.

$\checkmark$ Delivery (C3): The capability of transporting goods from a source location to the end-of customer. Ontime delivery performance are all goals of improved supplier performance.

$\checkmark$ Capacity (C4): The ability of human, commercial, and material resources that is related to product manufacturing.

$\checkmark \quad$ Smart warehouse and shelving system (C5): With the development of Industry 4.0 technologies, the raw materials store in the warehouse be able to track in real-time and check for space utilization. RFID scanner and sensors tags can provide more information about stock items, and communicate that to an inventory system, thereby the quantity of the remaining items, the quantity of raw materials ordered, and movement data of goods can be updated simultaneously [98]. Intelligent shelves detect and identify all goods that are placed between the RFID bookstands.

$\checkmark \quad$ Intelligent Transportation System such as GPS, RFID and dynamic sensors(C6): By integrating GPS technology placed into transport vehicles, it can monitor and learn all the relevant information (e.g., route, shipping conditions, and status of shipment) related to the smart goods being transported. With emerging of these technologies, the generated data is rapidly transferred from supplier to manufacturer and It can optimize the whole process of the transportation management system (TMS).

$\checkmark$ Employee training on Industry 4.0 (C7): Well-trained employees are less likely to make mistakes, more likely to be productive.

$\checkmark \quad$ Use of autonomous machine (C8): During the supply chain processes, computer-aided team systems and autonomous robots able to decrease the time spent on production, and the resources can be used more efficiently.

$\checkmark \quad$ Internet of Things (IoT) Implementation (C9): IoT applications provides access to real-time supply chain information by tracking materials in transit, products, and equipment as they move through the supply chain. This technology makes decisions that are more optimistic and faster than the other producers and suppliers.

$\checkmark$ Big data and Cloud computing (C10): In all supply chain processes, big size and variety numbers of data collected from all supply chain processes gain better insights on customer needs, forecasting ability in marketing, demand prediction, product development, and customer feedback.

\subsection{Determination of the relative weight of criteria}

In this section, the steps of IT2F-AHP which is defined in Section 3 are implemented in the following.

Step 1: The first step was to conduct a fuzzy pairwise comparison matrices that are formed using expert linguistic terms (given in Table 3). Expert evaluation of key criteria with respect to the goal is presented in Table 5. 
Table 5. Expert evaluation of criteria

$$
\text { C1 C2 }
$$

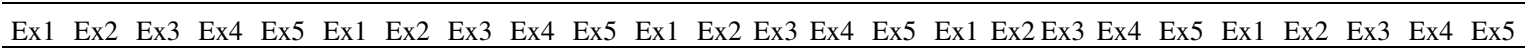

$\begin{array}{llllllllllllllllllllllllll}\text { C1 } & \text { E } & \text { E } & \text { E } & \text { E } & \text { E } & \text { E } & 1 / \text { WI } & 1 / S & 1 / S & \text { E } & \text { VS } & \text { WI } & \text { E } & 1 / \text { VS } & S & \text { VS } & \text { S } & \text { WI } & \text { E } & \text { S } & \text { AS } & \text { WI } & 1 / \text { WI } & 1 / S & S\end{array}$

$\begin{array}{llllllllllllllllllllllllllllllllllllll}\text { C2 } & \text { E } & \text { WI } & \text { S } & \text { S } & \text { E } & \text { E } & \text { E } & \text { E } & \text { E } & \text { E } & \text { VS } & S & \text { S } & 1 / \text { WI } & S & \text { VS } & \text { VS } & S & S & S & \text { AS } & \text { WI } & \text { WI } & \text { E } & S\end{array}$

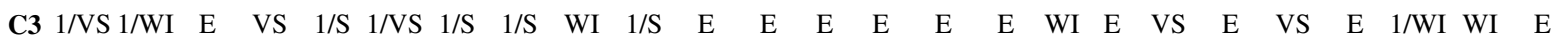

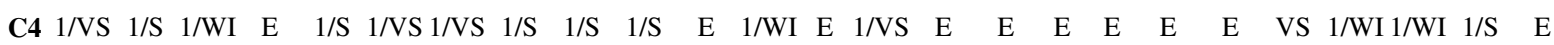

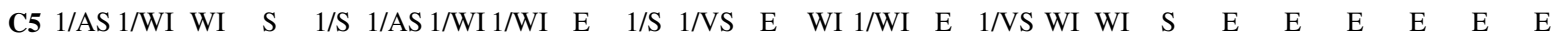

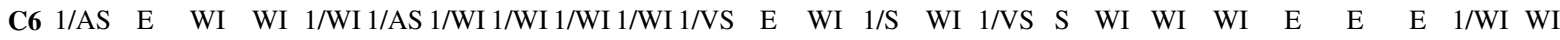
C7 1/AS 1/S 1/VS 1/WI 1/AS 1/AS 1/VS 1/VS 1/VS 1/AS 1/AS 1/WI 1/S 1/AS 1/S 1/AS 1/S 1/S 1/WI $1 / \mathrm{S} \quad 1 / \mathrm{WI} \quad 1 / \mathrm{S} \quad 1 / \mathrm{S} \quad 1 / \mathrm{VS} \quad 1 / \mathrm{S}$

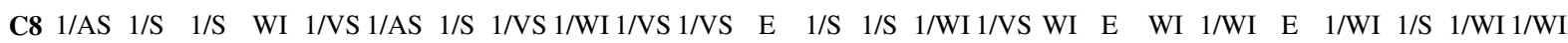

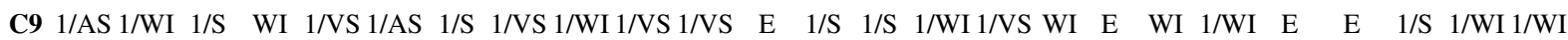
C10 1/AS 1/VS 1/VS 1/WI 1/AS 1/AS 1/VS 1/VS 1/VS 1/AS 1/VS 1/WI 1/S 1/AS 1/S 1/VS 1/S 1/S 1/WI $1 / \mathrm{S} \quad 1 / \mathrm{WI} \quad$ 1/S $\quad 1 / \mathrm{S} \quad 1 / \mathrm{VS} \quad 1 / \mathrm{S}$

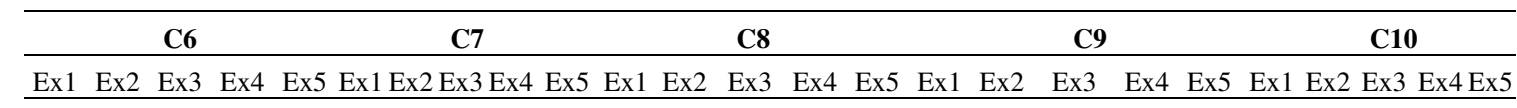

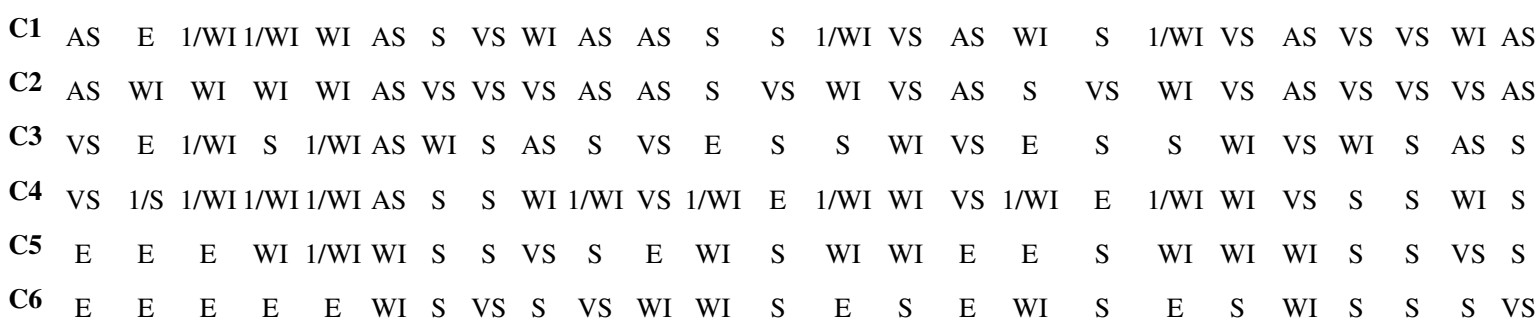

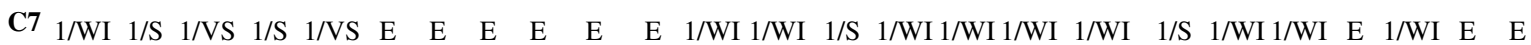

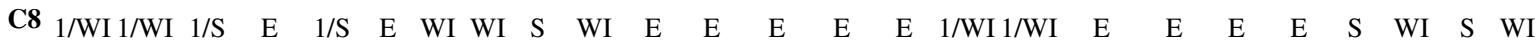

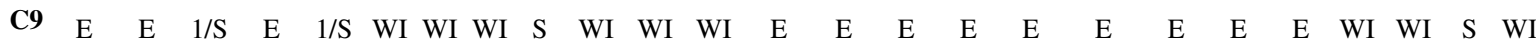

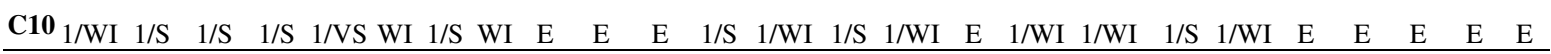

Step 2: After the experts' linguistic evaluation, the defuzzied pairwise matrices are checked their consistency ratio like traditional fuzzy AHP. For this purpose, the graded mean integration method is used for defuzzification [99]. According to result, the consistency ratio of pairwise comparison for each expert is calculated as 0.094, 0.065, $0.073,0.030,0.08$, respectively. All comparison matrices are consistent because of the consistency ratio found to be smaller than 0,10 .

Step 3: The aggregated comparison matrix of five experts is presented in Table 6. For example, the pairwise comparison of cost/ price (C1) and Internet of Things (IoT) Implementation (C9) is evaluated by five experts as linguistic terms (AS, WI, S, 1/WI, VS). Sample calculation is given as follow.

$\tilde{\tilde{a}}_{19}=[(7,8,9,9 ; 1,1)(7.2,8.2,8.8,9 ; 0.8,0.8) \times(1,2,4,5 ; 1,1)(1.2,2.2,3.8,4.8 ; 0.8,0.8)$

$\times(3,4,6,7 ; 1,1)(3.2,4.2,5.8,6.8 ; 0.8,0.8) \times(0.2,0.25,0.5,1 ; 1,1)(0.20,0.26,0.45,0.83 ; 0.8,0.8)$

$\times(5,6,8,9 ; 1,1)(5.2,6.2,7.8,8.8 ; 0.8,0.8)]^{1 / 5}$

$=(1.84,2.49,3.87,4.9 ; 1,1)(1.98,2.61,3.69,4.64 ; 0.8,0.8)$

Table 6. Aggregated expert performance by using IT2FS

\begin{tabular}{|c|c|c|c|c|}
\hline & $C 1$ & $C 2$ & $\ldots \ldots$ & $\mathrm{C10}$ \\
\hline C1 & $(1,1,1,1 ; 1,1)(1,1,1,1 ; 1,1)$ & $\begin{array}{c}(0.33,0.37,0.5,0.5 ; 1,1) \\
(0.34,0.38,0.48,0.6 ; 1,1)\end{array}$ & $\cdots \cdots$ & $\begin{array}{c}(4.15,5.4,7.3,8 ; 1,1) \\
(4.42,5.64,7.09,7.87 ; 1,1)\end{array}$ \\
\hline $\mathrm{C2}$ & $\begin{array}{c}(1.55,2,2.7,3 ; 1,1) \\
(1.65,2.08,2.64,2.95 ; 0.8,0.8)\end{array}$ & $(1,1,1,1 ; 1,1)(1,1,1,1 ; 1,1)$ & $\cdots \cdots$ & $\begin{array}{c}(5.72,6.73,8.39,9 ; 1,1) \\
(5.92,6.93,8.19,8.88 ; 0.8,0.8)\end{array}$ \\
\hline $\mathbf{C 3}$ & $\begin{array}{c}(0.43,0.51,0.7,0.9 ; 1,1) \\
(0.45,0.51,0.67,0.84 ; 0.8,0.8)\end{array}$ & $\begin{array}{c}(0.2,0.26,0.4,0.4 ; 1,1) \\
(0.21,0.27,0.38,0.49 ; 0.8,0.8)\end{array}$ & $\cdots \cdots$ & $\begin{array}{c}(3.16,4.34,6.36,7.24 ; 1,1) \\
(3.41,4.56,6.15,7.06 ; 0.8,0.8)\end{array}$ \\
\hline $\mathrm{C} 4$ & $\begin{array}{c}(0.21,0.25,0.35,0.47 ; 1,1) \\
(0.22,0.25,0.33,0.43 ; 0.8,0.8)\end{array}$ & $\begin{array}{c}(0.13,0.15,0.21,0.21 ; 1,1) \\
(0.13,0.15,0.2,0.25 ; 0.8,0.8)\end{array}$ & $\cdots \cdots$ & $\begin{array}{c}(2.67,3.78,5.86,6.88 ; 1,1) \\
(2.9,3.99,5.65,6.68 ; 0.8,0.8)\end{array}$ \\
\hline C5 & $\begin{array}{c}(0.39,0.52,0.83,1.1 ; 1,1) \\
(0.42,0.54,0.78,1.03 ; 0.8,0.8)\end{array}$ & $\begin{array}{c}(0.23,0.26,0.38,0.38 ; 1,1) \\
(0.24,0.26,0.36,0.5 ; 0.8,0.8)\end{array}$ & $\cdots \cdots$ & $\begin{array}{c}(2.67,3.78,5.86,6.88 ; 1,1) \\
(2.9,3.99,5.65,6.68 ; 0.8,0.8)\end{array}$ \\
\hline C6 & $\begin{array}{c}(0.47,0.64,1.01,1.28 ; 1,1) \\
(0.51,0.67,0.95,1.22 ; 0.8,0.8)\end{array}$ & $\begin{array}{c}(0.18,0.21,0.38,0.38 ; 1,1) \\
(0.18,0.22,0.35,0.58 ; 0.8,0.8)\end{array}$ & $\cdots \cdot$ & $\begin{array}{c}(2.67,3.78,5.86,6.88 ; 1,1) \\
(2.9,3.99,5.65,6.68 ; 0.8,0.8)\end{array}$ \\
\hline
\end{tabular}




\begin{tabular}{ccccc} 
& $(0.13,0.15,0.2,0.26 ; 1,1)$ & $(0.11,0.12,0.15,0.15 ; 1,1)$ & $\ldots . .53,0.57,0.76,1 ; 1,1)$ \\
C7 & $(0.13,0.15,0.19,0.25 ; 0.8,0.8)$ & $(0.11,0.12,0.14,0.17 ; 0.8,0.8)$ & $\ldots .$. & $(0.54,0.58,0.73,0.93 ; 0.8,0.8)$ \\
& $(0.19,0.24,0.35,0.43 ; 1,1)$ & $(0.13,0.15,0.22,0.22 ; 1,1)$ & & $(1.55,2.3,3.57,4.15 ; 1,1)$ \\
C8 & $(0.2,0.25,0.33,0.41 ; 0.8,0.8)$ & $(0.13,0.15,0.2,0.26 ; 0.8,0.8)$ & $\ldots .$. & $(1.71,2.43,3.45,4.03 ; 0.8,0.8)$ \\
& $(0.2,0.26,0.41,0.54 ; 1,1)$ & $(0.13,0.15,0.22,0.22 ; 1,1)$ & & $(1.25,2,3.29,3.88 ; 1,1)$ \\
C9 & $(0.21,0.27,0.38,0.51 ; 0.8,0.8)$ & $(0.13,0.15,0.2,0.26 ; 0.8,0.8)$ & $\ldots .$. & $(1.41,2.14,3.17,3.76 ; 0.8,0.8)$ \\
& $(0.12,0.14,0.19,0.24 ; 1,1)$ & $(0.11,0.12,0.15,0.15 ; 1,1)$ & & $(1,1,1,1 ; 1,1)(1,1,1,1 ; 0.8,0.8)$ \\
C10 & $(0.13,0.14,0.18,0.23 ; 0.8,0.8)$ & $(0.11,0.12,0.14,0.17 ; 0.8,0.8)$ & & \\
\hline
\end{tabular}

Step 4: After the aggregation of each experts' evaluation, the geometric means of each row is computed by using Eq.(16). The sample evaluation of the first raw $\left(\tilde{\tilde{r}}_{1}\right)$ is calculated as below: $\tilde{\tilde{r}}_{1}=[(1,1,1,1 ; 1,1)(1,1,1,1 ; 1,1) \mathrm{X}(0.33,0.37,0.5,0.5 ; 1,1)(0.34,0.38,0.48,0.6 ; 1,1) \mathrm{X}(1.11,1.44,2.01,2.01 ; 1,1)$ $(1.17,1.49,1.94,2.23 ; 1,1) X(1.11,2.86,4.1,4.1 ; 1,1)(2.3,2.99,3.98,4.55 ; 1,1) X(0.9,1.22,1.93,2.53 ; 1,1)$ $(0.97,1.27,1.84,2.38 ; 1,1) \times(0.78,1,1.55,2.14 ; 1,1)(0.82,1.04,1.47,1.97 ; 1,1)$ $\mathrm{X}(3.74,4.98,6.89,7.61 ; 1,1)(4.01,5.21,6.68,7.47 ; 1,1) \mathrm{X}(2.29,2.86,4.19,5.24 ; 1,1)(2.41,2.98,4.01,4.97 ; 1,1) \mathrm{X}$ $(1.84,2.49,3.87,4.9 ; 1,1)(1.98,2.61,3.69,4.64 ; 1,1) \times(4.15,5.4,7.3,8 ; 1,1)(4.42,5.64,7.09,7.87 ; 1,1)]^{1 / 10}=$ $(1.34,1.80,2.51,2.84 ; 1,1)(1.51,1.86,2.42,2.88 ; 0.8,0.8)$

Step 5: The priority IT2F weights of each criteria is determined by using Eq.(18). Geometric means and weights of the criteria are given in Table 7 . The computation of the first criterion $(\mathrm{C} 1)$ is offered in the following: $\widetilde{\widetilde{w}}_{i}=(1.34,1.8,2.51,2.85 ; 1,1)(1.51,1.87,2.42,2.88 ; 0.8,0.8)$ $\mathrm{X}[(1.34,1.8,2.51,2.85 ; 1,1)(1.51,1.87,2.42,2.88 ; 0.8,0.8)+(2.4,3.12,4.58,4.96 ; 1,1)(2.72,3.46,4.45,5.04 ; 0.8,0.8)$ $+(1.14,1.4,2.02,2.3 ; 1,1)(1.25,1.52,1.95,2.28 ; 0.8,0.8)+(0.55,0.67,1.04,1.3 ; 1,1)(0.62,0.74,0.99,1.27 ; 0.8,0.8)$ $+(0.83,1.07,1.64,1.83 ; 1,1)(0.94,1.19,1.58,1.89 ; 0.8,0.8)+(0.86,1.12,1.79,1.97 ; 1,1)(0.98,1.26,1.72,2.08 ; 0.8,0.8)$ $+(0.21,0.23,0.36,0.45 ; 1,1)(0.22,0.25,0.34,0.45 ; 0.8,0.8)+(0.38,0.47,0.75,0.88 ; 1,1)(0.44,0.53,0.71,0.9 ; 0.8,0.8)$ $+(0.44,0.56,0.88,0.99 ; 1,1)(0.51,0.63,0.84,1.02 ; 0.8,0.8)+(0.22,0.25,0.36,0.44 ; 1,1)(0.22,0.26,0.34,0.44 ; 0.8,0.8)]^{-1}$

Table 7. Geometric means of pairwise comparison matrix and IT2F weights

\begin{tabular}{|c|c|c|}
\hline & IT2F Geometric Mean & IT2F weights \\
\hline $\mathrm{C} 1$ & $(0.07,0.11,0.23,0.34 ; 1,1) "(0.08,0.12,0.21,0.31 ; 0.8,0.8)$ & $(0.07,0.11,0.23,0.34 ; 1,1) "(0.08,0.12,0.21,0.31 ; 0.8,0.8)$ \\
\hline $\mathrm{C} 2$ & $(0.13,0.2,0.43,0.59 ; 1,1) "(0.15,0.23,0.38,0.54 ; 0.8,0.8)$ & $(0.13,0.2,0.43,0.59 ; 1,1) "(0.15,0.23,0.38,0.54 ; 0.8,0.8)$ \\
\hline $\mathrm{C} 3$ & $(0.06,0.09,0.19,0.27 ; 1,1) "(0.07,0.1,0.17,0.24 ; 0.8,0.8)$ & $(0.06,0.09,0.19,0.27 ; 1,1) "(0.07,0.1,0.17,0.24 ; 0.8,0.8)$ \\
\hline $\mathrm{C} 4$ & $(0.03,0.04,0.1,0.16 ; 1,1) "(0.03,0.05,0.08,0.13 ; 0.8,0.8)$ & $(0.03,0.04,0.1,0.16 ; 1,1) "(0.03,0.05,0.08,0.13 ; 0.8,0.8)$ \\
\hline $\mathrm{C} 5$ & $(0.05,0.07,0.15,0.22 ; 1,1) "(0.05,0.08,0.14,0.2 ; 0.8,0.8)$ & $(0.05,0.07,0.15,0.22 ; 1,1) "(0.05,0.08,0.14,0.2 ; 0.8,0.8)$ \\
\hline C6 & $(0.05,0.07,0.17,0.24 ; 1,1) "(0.05,0.08,0.15,0.22 ; 0.8,0.8)$ & $(0.05,0.07,0.17,0.24 ; 1,1) "(0.05,0.08,0.15,0.22 ; 0.8,0.8)$ \\
\hline $\mathrm{C} 7$ & $(0.01,0.01,0.03,0.05 ; 1,1) "(0.01,0.02,0.03,0.05 ; 0.8,0.8)$ & $(0.01,0.01,0.03,0.05 ; 1,1) "(0.01,0.02,0.03,0.05 ; 0.8,0.8)$ \\
\hline $\mathrm{C} 8$ & $(0.02,0.03,0.07,0.11 ; 1,1) "(0.02,0.03,0.06,0.1 ; 0.8,0.8)$ & $(0.02,0.03,0.07,0.11 ; 1,1) "(0.02,0.03,0.06,0.1 ; 0.8,0.8)$ \\
\hline C9 & $(0.02,0.04,0.08,0.12 ; 1,1) "(0.03,0.04,0.07,0.11 ; 0.8,0.8)$ & $(0.02,0.04,0.08,0.12 ; 1,1) "(0.03,0.04,0.07,0.11 ; 0.8,0.8)$ \\
\hline $\mathrm{C} 10$ & $(0.01,0.02,0.03,0.05 ; 1,1) "(0.01,0.02,0.03,0.05 ; 0.8,0.8)$ & $(0.01,0.02,0.03,0.05 ; 1,1) "(0.01,0.02,0.03,0.05 ; 0.8,0.8)$ \\
\hline
\end{tabular}

Step 6: Finally, the IF2FSs is defuzzified by using center of area method [68] obtaining weights of each criterion using Eq. (19). For example, the defuzzified weights $\left(\widetilde{\widetilde{w}}_{1}\right)$ of the first criteria is calculated as follows:

$\left(\widetilde{\widetilde{w}}_{1}\right)=\frac{\frac{(0.34-0.07)+(0.85 \times 0.11-0.07)+(0.23-0.07)}{4}+0.07+\left[\frac{(0.30-0.08)+(0.4 * 0.12-0.08)+(0.06 * 0.20-0.08)}{4}+0.08\right]}{2}$

\section{Step 7: Normalized the defuzzified weights}

The normalized defuzzified weights of criteria are depicted in Figure 3. As shown in Fig.3, the "Quality"(C2), "Cost/price" (C1) and "Delivery"(C3) was the most important criteria respectively for selection process of the suppliers. 


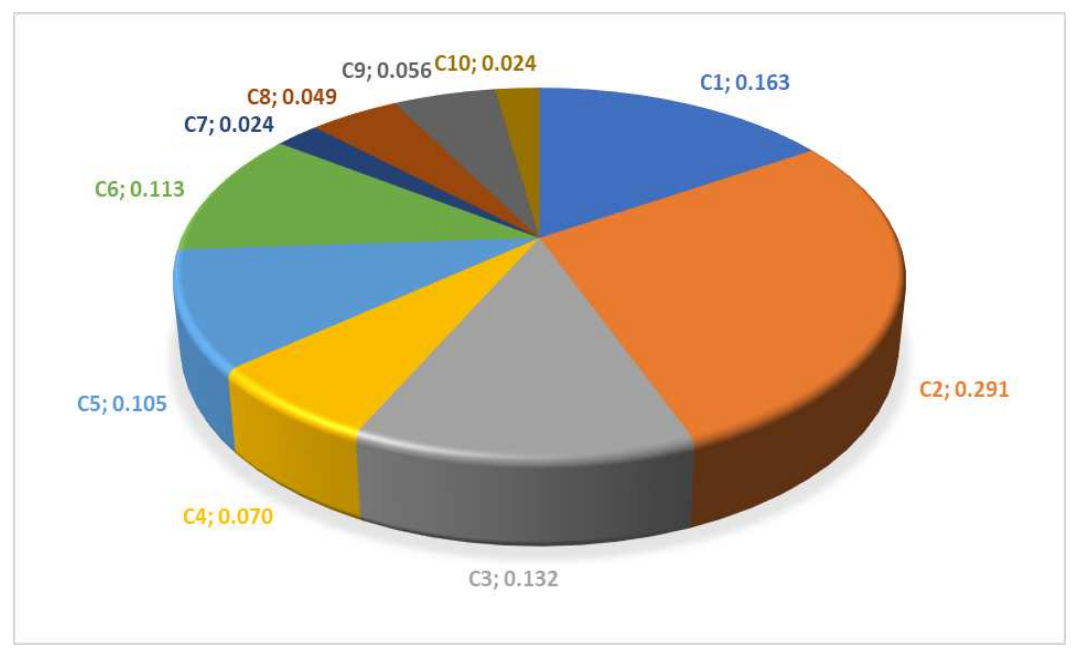

Fig 3. IT2FS and normalized weights of the criteria

\subsection{COPRAS-G Results}

Next, the COPRAS-G method and the importance weights found with the IT2F-AHP method were used to evaluate the four potential suppliers $\left(S_{1}, S_{2}, S_{3}, S_{4}\right)$. The linguistic evaluations of the decision makers according to the scale in Table 8 were converted to the group decision and the initial grey decision matrix $\otimes X$ was obtained by adding criterion weights to the matrix. The initial grey decision matrix is presented in Table 8 .

Table 8. The initial grey decision matrix

\begin{tabular}{|c|c|c|c|c|c|c|c|c|c|c|}
\hline \multirow{4}{*}{ Suppliers } & \multicolumn{10}{|l|}{ Criterion } \\
\hline & $\mathrm{C} 1$ & $\mathrm{C} 2$ & C3 & $\mathrm{C} 4$ & $\mathrm{C} 5$ & C6 & $\mathrm{C} 7$ & $\mathrm{C} 8$ & C9 & $\mathrm{C} 10$ \\
\hline & \multicolumn{10}{|l|}{ Weights } \\
\hline & 0,163 & 0,291 & 0,132 & 0,070 & 0,105 & 0,113 & 0,024 & 0,049 & 0,056 & 0,024 \\
\hline $\mathrm{S} 1$ & $6,4638,143$ & 5,$313 ; 6,868$ & 6,$463 ; 8,143$ & 4,$932 ; 6,463$ & 5,$241 ; 7,399$ & 5,$646 ; 7,862$ & 3,$915 ; 4,932$ & 4,$160 ; 5,646$ & 4,$217 ; 5,241$ & 2,$520 ; 4,217$ \\
\hline $\mathrm{S} 2$ & 4,$309 ; 5,313$ & 4,$642 ; 5,646$ & 5,$646 ; 7,862$ & 5,$313 ; 6,868$ & 4,$579 ; 6,082$ & 4,$932 ; 6,463$ & 4,$932 ; 6,463$ & 4,$309 ; 5,313$ & 4,$932 ; 6,463$ & 4,$642 ; 5,646$ \\
\hline S3 & 4,$642 ; 5,646$ & 4,$642 ; 5,646$ & 4,$932 ; 6,463$ & 6,$463 ; 8,143$ & 5,$241 ; 7,399$ & 5,$313 ; 6,868$ & 4,$642 ; 5,646$ & 4,$309 ; 5,313$ & 4,$160 ; 5,646$ & 4,$309 ; 5,313$ \\
\hline $\mathrm{S} 4$ & 4,$932 ; 6,463$ & 4,$309 ; 5,313$ & 5,$313 ; 6,868$ & 6,$868 ; 9,322$ & 6,$463 ; 8,143$ & 6,$463 ; 8,143$ & 3,$915 ; 4,932$ & 4,$579 ; 6,082$ & 4,$309 ; 5,313$ & 4,$309 ; 5,313$ \\
\hline
\end{tabular}

Since the criteria in the decision problem were evaluated according to the scale in Table 4, it was determined that the supplier alternatives that would receive the highest values for all criteria would be in the best condition.

The initial grey decision-matrix with interval values was normalized by using Eq (22) at the next step. The normalized decision matrix $\otimes \tilde{X}$ is presented in Table 9 .

Table 9. The normalized grey decision matrix

\begin{tabular}{|c|c|c|c|c|c|c|c|c|c|c|}
\hline \multirow{4}{*}{ Suppliers } & \multicolumn{10}{|l|}{ Criterion } \\
\hline & $\mathrm{C} 1$ & $\mathrm{C} 2$ & C3 & $\mathrm{C} 4$ & $\mathrm{C} 5$ & C6 & $\mathrm{C} 7$ & $\mathrm{C} 8$ & C9 & $\mathrm{C} 10$ \\
\hline & \multicolumn{10}{|l|}{ Weights } \\
\hline & 0,163 & 0,291 & 0,132 & 0,070 & 0,105 & 0,113 & 0,024 & 0,049 & 0,056 & 0,024 \\
\hline $\mathrm{S} 1$ & 0,$282 ; 0,355$ & 0,$251 ; 0,324$ & 0,$250 ; 0,315$ & 0,$181 ; 0,238$ & 0,$207 ; 0,293$ & 0,$218 ; 0,304$ & 0,$199 ; 0,251$ & 0,$210 ; 0,284$ & 0,$209 ; 0,260$ & 0,$139 ; 0,233$ \\
\hline $\mathrm{S} 2$ & 0,$188 ; 0,231$ & 0,$219 ; 0,266$ & 0,$218 ; 0,304$ & 0,$195 ; 0,253$ & 0,$181 ; 0,241$ & 0,$191 ; 0,250$ & 0,$251 ; 0,328$ & 0,$217 ; 0,268$ & 0,$245 ; 0,321$ & 0,$256 ; 0,311$ \\
\hline $\mathrm{S} 3$ & 0,$202 ; 0,246$ & 0,$219 ; 0,266$ & 0,$191 ; 0,250$ & 0,$238 ; 0,300$ & 0,$207 ; 0,293$ & 0,$206 ; 0,266$ & 0,$236 ; 0,287$ & 0,$217 ; 0,268$ & 0,$207 ; 0,280$ & 0,$238 ; 0,293$ \\
\hline $\mathrm{S} 4$ & 0,$215 ; 0,282$ & 0,$203 ; 0,251$ & 0,$206 ; 0,266$ & 0,$253 ; 0,343$ & 0,$256 ; 0,322$ & 0,$250 ; 0,315$ & 0,$199 ; 0,251$ & 0,$231 ; 0,306$ & 0,$214 ; 0,264$ & 0,$238 ; 0,293$ \\
\hline
\end{tabular}

After the normalizing process, the weights obtained by IT2F-AHP method are effected in normalized decision matrix in order to develop the weighted normalized grey decision matrix. The weighted normalized grey decisionmaking matrix $(\otimes \hat{X})$ is presented in Table 10 was constructed next by using Eq (24). 
Table 10. The weighted normalize grey decision matrix

\begin{tabular}{|c|c|c|c|c|c|c|c|c|c|c|}
\hline \multirow{2}{*}{ Suppliers } & \multicolumn{10}{|l|}{ Criterion } \\
\hline & $\mathrm{C} 1$ & $\mathrm{C} 2$ & C3 & $\mathrm{C} 4$ & $\mathrm{C} 5$ & C6 & $\mathrm{C7}$ & $\mathrm{C} 8$ & C9 & C10 \\
\hline $\mathrm{S} 1$ & 0,$046 ; 0,058$ & 0,$073 ; 0,094$ & 0,$033 ; 0,042$ & 0,$013 ; 0,017$ & 0,$022 ; 0,031$ & 0,$025 ; 0,034$ & 0,$005 ; 0,006$ & 0,$010 ; 0,014$ & 0,$012 ; 0,015$ & 0,$003 ; 0,006$ \\
\hline $\mathrm{S} 2$ & 0,$031 ; 0,038$ & 0,$064 ; 0,078$ & 0,$029 ; 0,040$ & 0,$014 ; 0,018$ & 0,$019 ; 0,025$ & 0,$022 ; 0,028$ & 0,$006 ; 0,008$ & 0,$011 ; 0,013$ & 0,$014 ; 0,018$ & 0,$006 ; 0,007$ \\
\hline S3 & 0,$033 ; 0,040$ & 0,$064 ; 0,078$ & 0,$025 ; 0,033$ & 0,$017 ; 0,021$ & 0,$022 ; 0,031$ & 0,$023 ; 0,030$ & 0,$006 ; 0,007$ & 0,$011 ; 0,013$ & 0,$012 ; 0,016$ & 0,$006 ; 0,007$ \\
\hline $\mathrm{S} 4$ & 0,$035 ; 0,046$ & 0,$059 ; 0,073$ & 0,$027 ; 0,035$ & 0,$018 ; 0,024$ & 0,$027 ; 0,034$ & 0,$028 ; 0,036$ & 0,$005 ; 0,006$ & 0,$011 ; 0,015$ & 0,$012 ; 0,015$ & 0,$006 ; 0,007$ \\
\hline
\end{tabular}

We followed the next steps described earlier and determined the relative importance of each alternative by calculating $P_{j}$ using Eq. (26) and $Q_{j}$ using Eq. (29). Hence in the decision-making matrix there will not be any nonbeneficial criteria and the relative importance " $\mathrm{Q}_{\mathrm{j}}$ " should be equal to the $\mathrm{P}_{\mathrm{j}}$. At the last step, we determined the utility degree of each alternative $\left(\mathrm{N}_{\mathrm{j}}\right)$ by using Eq. (31). Table 11 presents the $\mathrm{P}_{\mathrm{j}}, \mathrm{Q}_{\mathrm{j}}$ and $\mathrm{N}_{\mathrm{j}}$ for the four supplier alternatives under consideration.

Table 11. The evaluation of utility degree and supplier ranking

\begin{tabular}{ccccc}
\hline & $\mathrm{P}_{\mathrm{j}}$ & $\mathrm{Q}_{\mathrm{j}}$ & $\mathrm{N}_{\mathrm{j}}$ & Rank \\
\hline S1 & 0,2784 & 0,2784 & 1,0000 & 1 \\
S2 & 0,2435 & 0,2435 & 0,8748 & 4 \\
S3 & 0,2461 & 0,2461 & 0,8841 & 3 \\
S4 & 0,2590 & 0,2590 & 0,9306 & 2 \\
\hline
\end{tabular}

As shown in Table 11, Supplier 1 (S1) with a utility degree of $100 \%$ was selected as the best supplier for this case study. Supplier 4 (S4) with a utility degree of $93.06 \%$ was the second ranking, Supplier 3 (S3) with a utility degree of $88.41 \%$ was the third ranking and Supplier 2 (S2) with utility a degree of $87.48 \%$ was selected the worst supplier alternative. In summary, $\mathrm{S} 1>\mathrm{S} 4>\mathrm{S} 3>\mathrm{S} 2$.

\section{Sensitivity Analysis and Discussion}

In this section, the sensitivity analysis is divided into two main separated scenarios. The first scenario is a comparison of the results with other MCDM methods. Previously results obtained by IT2F-AHP and COPRAS-G are compared using other integrated grey MCDM methods like TOPSIS-G, WASPAS-G and ARAS-G. In the first scenario, criteria weights are obtained by IT2F-AHP. The second scenario covers a sensitivity analysis of the ranks of the suppliers related to changes in the weight of the criteria. In this scenario, criteria weights are taken into consideration at equal importance.

A comparison between the ranks of suppliers obtained from different methods for two scenarios is demonstrated in Figure 4.

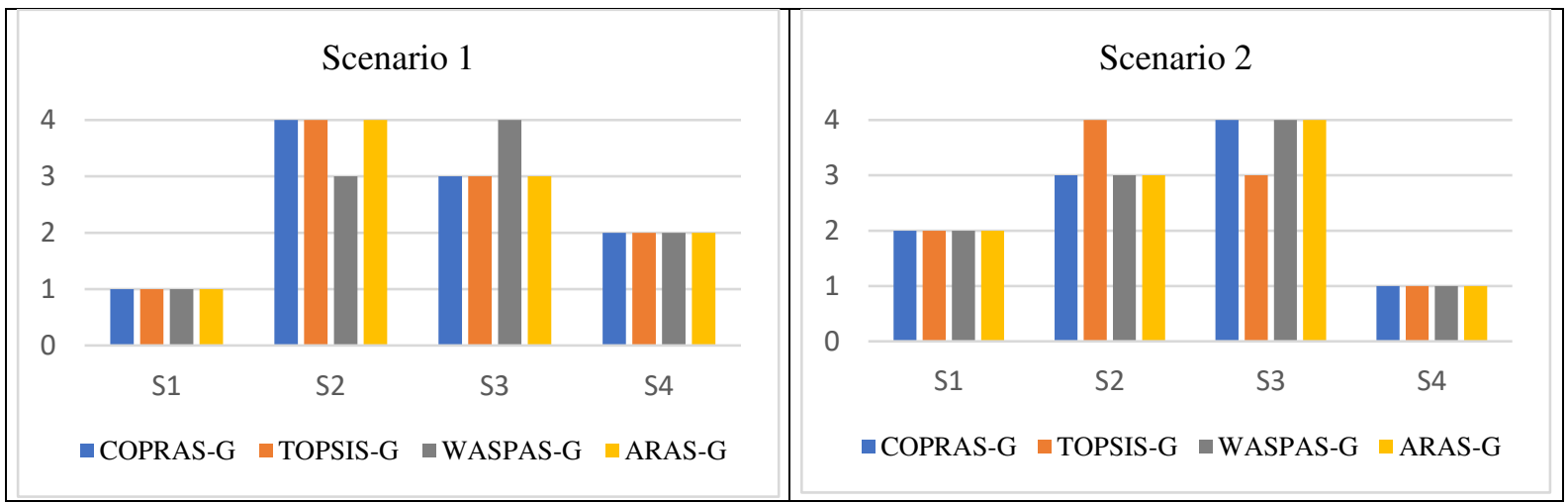

Fig 4. The ranking of suppliers (Scenario 1 and Scenario 2)

For Scenario 1, the supplier S1 took the highest rank and, the supplier S2 takes the second rank among to all the methods. Considering the WASPAS-G method, only one rank change determined where supplier S2 and supplier S3 change their places, taking the $3^{\text {rd }}$ and $4^{\text {th }}$ rank, respectively.

For Scenario 2, the supplier S2 took the highest rank and, the supplier S1 takes the second rank among to all the methods. Considering the TOPSIS-G method, only one rank change determined where supplier S2 and supplier S3 change their places, taking the $4^{\text {rd }}$ and $3^{\text {th }}$ rank, respectively. 
The statistical correlation of supplier ranks for each scenario is computed using Spearman's correlation coefficient. Results are shown in Table 12.

Table 12. The correlation of supplier ranks

\begin{tabular}{cccccc}
\hline Spearman's coefficient & COPRAS-G & TOPSIS-G & WASPAS-G & ARAS-G & $\begin{array}{c}\text { Average } \\
\text { value }\end{array}$ \\
\hline Scenario 1 & 1 & 1 & 0,800 & 1 & 0,95 \\
Scenario 2 & 1 & 0,800 & 1 & 1 & 0,95 \\
\hline
\end{tabular}

The overall correlation values demonstrate a significant correlation between the ranks of the different grey integrated MCDM methods for each scenario. COPRAS-G, TOPSIS-G and ARAS-G are consistent and there is no change between the ranks for Scenario 1. The WASPAS-G method has a slightly lower correlation compared to other methods.

COPRAS-G, WASPAS-G and ARAS-G are consistent and there is no change between the ranks in terms of the results of the Scenario 2. The TOPSIS-G method has a slightly lower correlation compared to other methods.

\section{Managerial Implication}

Supplier selection is one of the important decision-making problems for companies. Businesses make a difference between their competitors and suppliers to achieve their goals. It should be careful in choosing and work with the right suppliers. With Industry 4.0, it is aimed to create a radical change in competitiveness, innovation, flexibility, individuality and working conditions by placing the customer at the center of a digital platform where companies' supply chains turn into supply networks. They are willing to need new requirements for their own suppliers in accordance with Industry 4.0 implementation process.

On the other side, it has some managerial implications for the industry. The proposed model is developed for a high-textile manufacturer. Although this study considers Industry 4.0 technologies criteria in supplier selection of a textile company, it can be adapted to one another industry and sector due to the widespread use of industry 4.0. Industry 4.0 is easy to adapt to any fields therefore, this study also provides guidance to economists, managers, IT specialist, industry experts, and companies working in different type of industries and sectors, as well as researchers working in the field of supply chain, innovation and Industry 4.0.

\section{Conclusions and limitations}

This paper has illustrated an integrated approach based on IT2F-AHP and COPRAS-G methods for the supplier selection process in a textile manufacturing company. While economic, environmental, and social aspects of supplier selection process have been discussed in the previous studies, less attention has been paid to Industry 4.0 technologies and processes. Therefore, the criteria within the scope of the study were determined by considering the components of Industry 4.0 and the traditional ones such as cost, quality, delivery, and capacity. An IT2F-AHP approach was applied to determine the weights of criteria and then COPRAS-G approach was proposed to select the most suitable supplier alternative.

Sensitivity analysis was conducted to test the validity of the hybrid approach prepared and two different scenarios were developed. In the first scenario, the results obtained with the COPRAS-G method were compared with traditional and novel MCDM methods such as TOPSIS-G, WASPAS-G, ARAS-G. According to the result, the supplier S1 is considered to be the best alternative for all grey MCDM. This Spearman's correlation coefficient calculated to determine the relationships between the methods was found as 0.95 value. It has been observed that the different type MCDM methods with grey numbers used give highly effective results to determine the ranking of suppliers. In the scenario 2, suppliers were ranked under the assumption that the weight of supplier selection criteria was equally important. The weights of Industry 4.0 criteria such as Employee training on Industry 4.0 (C7), Use of autonomous machine (C8), Internet of Things (IoT) Implementation (C9), Big data and Cloud computing (C10) have increased in the second scenario therefore, the supplier S2 took the highest rank. In the light of the sensitivity analysis, It is revealed that decision makers pay more attention to traditional supplier selection criteria (Cost/price, Quality and Delivery) than Industry 4.0 technology criteria (Employee training on Industry 4.0, Use of autonomous machine, Internet of Things (IoT) Implementation, Big data and Cloud computing).

This paper presented a real case study and demonstrated the applicability of the proposed framework. This model presented an integrated IT2F-AHP and COPRAS-G method. IT2F-AHP can adopted to different real-life problems $[12,15,100,101,102]$. There have been many real-life studies using COPRAS-G recently. These studies are: selection of the coal-fired thermal power plants [103], machine tool selection [16], banking website selection [104], media platform selection [105], supplier selection [106]. Both methods are easily applied to real life problems. It is observed that this new hybrid methodologies can be practically adopted to different type of reallife problem. 
The study has some limitations. As industry 4.0 is very new topic for Turkish company, it is exceedingly difficult to find experienced experts in this field. Furthermore, we have assumed equal importance degree to the experts. We are planning to uncover these limitations in our future study. Expert weighting can be added to the further study, considering some characteristics such as age, education level, title, and year experience in the industry. For the future studies, as the number of papers on supplier selection considering the Industry 4.0 is rising, this new hybrid model can compare the reliability and validity of other MCDM approaches under different sectors and conditions. In this study, IT2F-AHP method was applied to determine the weights of supplier selection criteria. Further study, novel MCDM methods like Stepwise Weight Assessment Ratio Analysis (SWARA), Best Worst Method (BWM) and Full Consistency Method (FUCOM) can be employed to weight the selection criteria. Furthermore, the obtained results from these novel methods can be compared by our results. Additionally, different types of fuzzy set theories that have recently been popular, such as Pythagorean fuzzy sets, spherical fuzzy sets, and hexagonal fuzzy sets, can also be applied for the further study. By doing this, a comparative framework may be developed and used to examine the reliability of the integration of IT2F-AHP and other types of fuzzy sets.

\section{Declaration of computing interest}

The authors declare that they have no known competing financial interests or personal relations that could have appeared to influence the work reported in this study.

\section{Acknowledgments}

The authors would like to thank the worthy referees and editor for their valuable suggestions for our paper in Neural Computing and Application.

\section{References}

1. Hermann M, Pentek T, Otto B (2016) Design Principles for Industrie 4.0 Scenarios. 49th Hawaii International Conference on System Sciences (HICSS), 3928-3937. IEEE.

2. Muhammad Ashraf W., Uddin GM., Arafat SM., Afghan S., Kamal AH., Asim M., ... Krzywanski J (2020) Optimization of a 660 MWe Supercritical Power Plant Performance-A Case of Industry 4.0 in the DataDriven Operational Management Part 1. Thermal Efficiency. Energies 13: 5592.

3. Muhammad Ashraf W, Moeen Uddin G, Hassan Kamal A, Haider Khan M, Khan AA, Afroze Ahmad H, ... Krzywanski, J (2020). Optimization of a 660 MWe Supercritical Power Plant Performance-A Case of Industry 4.0 in the Data-Driven Operational Management. Part 2. Power Generation. Energies 13(21): 5619.

4. Kabugo JC, Jämsä-Jounela SL, Schiemann R, Binder, C (2020). Industry 4.0 based process data analytics platform: A waste-to-energy plant case study. International journal of electrical power \& energy systems 115 : 105508.

5. Sultana I, Ahmed I, Azeem A (2015) An integrated approach for multiple criteria supplier selection combining Fuzzy Delphi, Fuzzy AHP \& Fuzzy TOPSIS. Journal of intelligent \& fuzzy systems 29(4): 12731287.

6. Sepehriar A, Eslamipoor R, Nobari, A (2013) A new mixed fuzzy-LP method for selecting the best supplier using fuzzy group decision making. Neural computing and applications 23(1): 345-352.

7. Fallahpour A, Olugu, EU, Musa, SN (2017) A hybrid model for supplier selection: integration of AHP and multi expression programming (MEP). Neural computing and applications 28(3): 499-504.

8. John R, Coupland S (2007) Type-2 fuzzy logic: A historical view. IEEE computational intelligence magazine 2(1): 57-62.

9. Mendel JM (2007) Type-2 fuzzy sets and systems: an overview. IEEE computational intelligence magazine 2(1): 20-29.

10. Wu H, Wu Y, Luo J (2009) An interval type-2 fuzzy rough set model for attribute reduction. IEEE Transactions on fuzzy systems 17(2): 301-315.

11. Aksoy E, Ömürbek N, Karaatli M (2015) AHP Temelli MULTIMOORA ve COPRAS yöntemi ile Türkiye Kömür İşletmeleri'nin performans değerlendirmesi. Hacettepe üniversitesi iktisadi ve idari bilimler fakültesi dergisi 33(4): 1-28.

12. Kahraman C, Öztayşi B, Sarı İU, Turanoğlu E (2014) Fuzzy analytic hierarchy process with interval type-2 fuzzy sets. Knowledge-based systems 59: 48-57.

13. Chan FT, Kumar N (2007) Global supplier development considering risk factors using fuzzy extended AHPbased approach. Omega 35(4): 417-431. 
14. Ghorabaee MK (2016) Developing an MCDM method for robot selection with interval type-2 fuzzy sets. Robotics and Computer-Integrated Manufacturing 37, 221-232.

15. Ecer F (2020) Multi-criteria decision making for green supplier selection using interval type-2 fuzzy AHP: a case study of a home appliance manufacturer. Operational Research 1-35.

16. Aghdaie MH, Zolfani SH, Zavadskas EK (2013) Decision making in machine tool selection: An integrated approach with SWARA and COPRAS-G methods. Engineering economics 24(1): 5-17.

17. Chan, F.T.S. \& Kumar, N. 2007. Global supplier development considering risk factors using fuzzy extended AHP-based approach. OMEGA - International Journal of Management Science, 3(4), pp. 417-431.

18. Khorasani, O. \& Bafruei, M.K. 2011. A fuzzy AHP approach for evaluating and selecting supplier in pharmaceutical industry. International Journal of Academic Research, 3(1), pp. 346-352.

19. Rezaei, J., Fahim, P.B. \& Tavasszy, L. 2014. Supplier selection in the airline retail industry using a funnel methodology: Conjunctive screening method and fuzzy AHP. Expert Systems with Applications, 41(18), pp. 8165-8179.

20. Wei, J.Y., Sun, A.F. \& Wang, C.H. 2010. The application of fuzzy-ANP in the selection of supplier in supply chain management. International Conference on Logistics Systems and Intelligent Management, pp. 13571360.

21. Dargi, A., Anjomshoae, A., Galankashi, M.R., Memari, A. \& Tap, M.B.M. 2014. Supplier selection: A fuzzyANP approach. Procedia Computer Science, 31, pp. 691-700.

22. Wang, J.V., Cheng, C.H. \& Kun-Cheng, H. 2009. Fuzzy hierarchical TOPSIS for supplier selection. Applied Soft Computing, 9, pp. 377-386

23. Kannan, G., Pokharel, S., \& Kumar, P. S. (2009). A hybrid approach using ISM and fuzzy TOPSIS for the selection of reverse logistics provider. Resources, conservation and recycling, 54(1), 28-36.

24. Akman G (2014) Evaluating suppliers to include green supplier development programs via fuzzy c-means and VIKOR methods. Comput Ind Eng 86:69-82.

25. Mousakhani, S., Nazari-Shirkouhi, S., \& Bozorgi-Amiri, A. (2017). A novel interval type-2 fuzzy evaluation model based group decision analysis for green supplier selection problems: A case study of battery industry. Journal of cleaner production, 168, 205-218.

26. Gupta, S., Soni, U., \& Kumar, G. (2019). Green supplier selection using multi-criterion decision making under fuzzy environment: A case study in automotive industry. Computers \& Industrial Engineering, 136, 663-680.

27. Kahraman C, Cebeci U, Ulukan Z. (2003) Multi-criteria supplier selection using fuzzy AHP. Logistics information management 16(6): 382-394.

28. Chan FT, Kumar N (2007) Global supplier development considering risk factors using fuzzy extended AHPbased approach. Omega 35(4): 417-431.

29. Bottani E, Rizzi A (2008) An adapted multi-criteria approach to suppliers and products selection-an application oriented to lead-time reduction. International Journal of Production Economics 111(2): 763-781.

30. Lee AH (2009) A fuzzy supplier selection model with the consideration of benefits, opportunities, costs and risks. Expert systems with applications 36(2): 2879-2893.

31. Chamodrakas I, Batis D, Martakos D (2010) Supplier selection in electronic marketplaces using satisficing and fuzzy AHP. Expert systems with applications 37(1): 490-498.

32. Şen CG, Şen S, Başlıgil H (2010) Pre-selection of suppliers through an integrated fuzzy analytic hierarchy process and max-min methodology. International journal of production research 48(6): 1603-1625.

33. Amid A, Ghodsypour SH, O’Brien C (2011) A weighted max-min model for fuzzy multi-objective supplier selection in a supply chain. International Journal of production economics 131(1): 139-145.

34. Kilincci O, Onal SA (2011) Fuzzy AHP approach for supplier selection in a washing machine company. Expert systems with applications 38(8): 9656-9664.

35. Chen YH, Chao RJ (2012) Supplier selection using consistent fuzzy preference relations. Expert systems with applications 39(3): 3233-3240.

36. Wang J, Cheng C, Huang K (2009) Fuzzy hierarchical TOPSIS for supplier selection. Applied soft computing journal 9(1): 377-386.

37. Zeydan M, Çolpan C, Çobanoğlu C (2011) A combined methodology for supplier selection and performance evaluation. Expert systems with applications 38(3): 2741-2751.

38. Kannan D, Khodaverdi R, Olfat L, Jafarian A, Diabat A (2013) Integrated fuzzy multi criteria decision making method and multi-objective programming approach for supplier selection and order allocation in a green supply chain. Journal of cleaner production 47: 355-367. 
39. Junior FRL, Osiro L, Carpinetti LCR (2014) A comparison between Fuzzy AHP and Fuzzy TOPSIS methods to supplier selection. Applied soft computing 21: 194-209.

40. Jain V, Sangaiah AK, Sakhuja S, Thoduka N, Aggarwal R. (2018) Supplier selection using fuzzy AHP and TOPSIS: a case study in the Indian automotive industry. Neural computing and applications 29(7): 555-564.

41. Amin SH, Razmi J (2009) An integrated fuzzy model for supplier management: A case study of ISP selection and evaluation. Expert systems with applications 36(4): 8639-8648.

42. Razmi J, Rafiei H, Hashemi M (2009) Designing a decision support system to evaluate and select suppliers using fuzzy analytic network process. Computers \& Industrial Engineering 57(4): 1282-1290.

43. Önüt S, Kara SS, Işik E (2009) Long term supplier selection using a combined fuzzy MCDM approach: A case study for a telecommunication company. Expert systems with applications 36(2): 3887-3895.

44. Büyüközkan G, Çifçi G (2011) A novel fuzzy multi-criteria decision framework for sustainable supplier selection with incomplete information. Computers in industry 62(2): 164-174.

45. Vinodh S, Ramiya RA, Gautham SG (2011) Application of fuzzy analytic network process for supplier selection in a manufacturing organisation. Expert systems with applications 38(1): 272-280.

46. Chen CT, Lin CT, Huang SF (2006) A fuzzy approach for supplier evaluation and selection in supply chain management. International journal of production economics 102(2): 289-301.

47. Boran FE, Genç S, Kurt M, Akay D (2009) A multi-criteria intuitionistic fuzzy group decision making for supplier selection with TOPSIS method. Expert systems with applications 36(8): 11363-11368.

48. Buyukozkan G, Ersoy MS (2009) Applying fuzzy decision-making approach to IT outsourcing supplier selection. World Academy Science -Engineering and technology, 55: 411-415.

49. Awasthi A, Chauhan SS, Goyal SK (2010) A fuzzy multicriteria approach for evaluating environmental performance of suppliers. International journal of production economics 126(2): 370-378.

50. Liao CN, Kao HP (2011) An integrated fuzzy TOPSIS and MCGP approach to supplier selection in supply chain management. Expert systems with applications 38(9): 10803-10811.

51. Buyukozkan G, Cifci G (2012) A novel hybrid MCDM approach based on fuzzy DEMATEL, fuzzy ANP and fuzzy TOPSIS to evaluate green suppliers. Expert systems with applications 39(3): 3000-3011

52. Montazer GA, Saremi HQ, Ramezani M (2009) Design a new mixed expert decision aiding system using fuzzy ELECTRE III method for vendor selection. Expert systems with applications 36(8): 10837-10847.

53. Sevkli M (2010) An application of the fuzzy ELECTRE method for supplier selection. International journal of production research 48(12): 3393-3405.

54. Dalalah D, Hayajneh M, Batieha F (2011) A fuzzy multi-criteria decision-making model for supplier selection. Expert systems with applications 38(7): 8384-8391.

55. Chen LY, Wang TC (2009) Optimizing partners' choice in IS/IT outsourcing projects: The strategic decision of fuzzy VIKOR. International journal of production economics 120(1): 233-242.

56. Sanayei A, Mousavi SF, Yazdankhah A (2010) Group decision making process for supplier selection with VIKOR under fuzzy environment. Expert systems with applications 37(1): 24-30.

57. Shemshadi A, Shirazi H, Toreihi M, Tarokh MJ (2011) A fuzzy VIKOR method for supplier selection based on entropy measure for objective weighting. Expert systems with applications 38(10): 12160-12167.

58. Chai J, Liu JN, Xu Z (2012) A new rule-based SIR approach to supplier selection under intuitionistic fuzzy environments.International journal of uncertainty, fuzziness and knowledge-based systems 20(03): 451-471.

59. Badi I, Ballem M (2018) Supplier selection using the rough BWM-MAIRCA model: A case study in pharmaceutical supplying in Libya. Decision Making: Applications in management and engineering 1(2):1633.

60. Liu F, Aiwu G, Lukovac V, Vukic M (2018) A multicriteria model for the selection of the transport service provider: A single valued neutrosophic DEMATEL multicriteria model. Decision making: Applications in management and engineering 1(2): 121-130.

61. Stević Ž, Durmić E, Gajić M, Pamučar D, Puška A (2019) A Novel Multi-Criteria Decision-Making Model: Interval Rough SAW Method for Sustainable Supplier Selection. Information 10(10): 292.

62. Kumari R, Mishra AR (2020) Multi-criteria COPRAS Method Based on Parametric Measures for Intuitionistic Fuzzy Sets: Application of Green Supplier Selection. Iranian Journal of Science and Technology, Transactions of Electrical Engineering 1-18.

63. Peng JJ, Tian C, Zhang WY, Zhang S, Wang JQ (2020) An integrated multi-criteria decision-making framework for sustainable supplier selection under picture fuzzy environment. Technological and Economic Development of Economy 26(3), 573-598. 
64. Phochanikorn P, Tan C (2019) An integrated multi-criteria decision-making model based on prospect theory for green supplier selection under uncertain environment: A case study of the Thailand palm oil products industry. Sustainability 11(7), 1872.

65. Bolturk E (2018) Pythagorean fuzzy CODAS and its application to supplier selection in a manufacturing firm. Journal of Enterprise Information Management 31(4), 550-564.

66. Junior FRL, Osiro L, Carpinetti LCR (2014) A comparison between Fuzzy AHP and Fuzzy TOPSIS methods to supplier selection. Applied soft computing 21: 194-209.

67. Dargi A, Anjomshoae A, Galankashi MR, Memari A, Tap MBM (2014) Supplier selection: A fuzzy-ANP approach. Procedia computer science 31: 691-700.

68. Rezaei J, Fahim PB, Tavasszy L (2014) Supplier selection in the airline retail industry using a funnel methodology: Conjunctive screening method and fuzzy AHP. Expert systems with applications 41(18): 81658179 .

69. Kar AK (2014) Revisiting the supplier selection problem: An integrated approach for group decision support. Expert systems with applications 41(6): 2762-2771.

70. Chen PS, Wu MT (2013) A modified failure mode and effects analysis method for supplier selection problems in the supply chain risk environment: A case study. Computers \& industrial engineering 66(4): 634642.

71. Rajesh G, Malliga P (2013) Supplier selection based on AHP QFD methodology. Procedia engineering 64: 1283-1292.

72. Bruno G, Esposito E, Genovese A, Passaro R (2012) AHP-based approaches for supplier evaluation: Problems and perspectives. Journal of purchasing and supply management 18(3): 159-172.

73. Lin RH (2012) An integrated model for supplier selection under a fuzzy situation. International journal of production economics 138(1): 55-61.

74. Asamoah D, Annan J, Nyarko S (2012) AHP approach for supplier evaluation and selection in a pharmaceutical manufacturing firm in Ghana. International journal of business and management 7(10): 4962.

75. Mafakheri F, Breton M, Ghoniem A (2011) Supplier selection-order allocation: A two-stage multiple criteria dynamic programming approach. International journal of production economics 132(1): 52-57.

76. Khorasani O, Bafruei MK (2011) A fuzzy AHP approach for evaluating and selecting supplier in pharmaceutical industry. International journal of academic research 3(1): 346-352.

77. Aksoy A, Öztürk N (2011) Supplier selection and performance evaluation in just-in-time production environments. Expert systems with applications 38(5): 6351-6359.

78. Wei JY, Sun AF, Wang CH (2010) The application of fuzzy-ANP in the selection of supplier in supply chain management. 2010 International Conference on Logistics Systems and Intelligent Management (ICLSIM) 3: 1357-1360.

79. Jolai F, Yazdian SA, Shahanaghi K, Khojasteh MA (2011) Integrating fuzzy TOPSIS and multi-period goal programming for purchasing multiple products from multiple suppliers. Journal of purchasing and supply management 17(1): 42-53.

80. Kuo RJ, Wang YC, Tien FC (2010) Integration of artificial neural network and MADA methods for green supplier selection. Journal of cleaner production 18(12): 1161-1170.

81. Mendoza A, Santiago E, Ravindran AR (2008) A three-phase multicriteria method to the supplier selection problem. International journal of industrial engineering 15(2): 195-210.

82. Mendel JM, John RI, Liu F (2006) Interval type-2 fuzzy logic systems made simple. IEEE transactions on fuzzy systems 14(6): 808-821.

83. Zadeh LA (1975) The concept of a linguistic variable and its application to approximate reasoning-I. Information sciences 8(3): 199-249.

84. Liang Q, Mendel JM (2000) Interval type-2 fuzzy logic systems: theory and design. IEEE Transactions on fuzzy systems 8(5): 535-550.

85. Mendel J, Wu D (2010) Perceptual computing: Aiding people in making subjective judgments (Vol. 13). John Wiley \& Sons.

86. Chen SM, Lee LW (2010) Fuzzy multiple attributes group decision-making based on the interval type-2 TOPSIS method. Expert systems with applications 37(4): 2790-2798.

87. Lee LW, Chen SM (2008) Fuzzy multiple attributes group decision-making based on the extension of TOPSIS method and interval type-2 fuzzy sets. In 2008 International Conference on Machine Learning and Cybernetics 6: 3260-3265. 
88. Saaty TL (1977) A scaling method for priorities in hierarchical structures. Journal of mathematical psychology 15(3): 234-281.

89. Bevilacqua M, Ciarapica FE, Giacchetta G (2006) A fuzzy-QFD approach to supplier selection. Journal of purchasing and supply management 12(1): 14-27.

90. Zadeh LA (1965) Fuzzy sets. Information and control 8(3): 338-353.

91. Wang TC, Chen YH (2008) Applying fuzzy linguistic preference relations to the improvement of consistency of fuzzy AHP. Information sciences 178(19): 3755-3765.

92. Van Laarhoven PJ, Pedrycz W (1983) A fuzzy extension of Saaty's priority theory. Fuzzy sets and systems 11(1-3): 229-241.

93. Buckley JJ (1985) Fuzzy hierarchical analysis. Fuzzy sets and systems 17(3): 233-247.

94. Chang DY (1996) Applications of the extent analysis method on fuzzy AHP. European journal of operational research 95(3): 649-655.

95. Zavadskas EK, Kaklauskas A, Turskis Z, Tamošaitienė J (2009) Multi-attribute decision-making model by applying grey numbers. Informatica 20(2): 305-320.

96. Tavana M, Momeni E, Rezaeiniya N, Mirhedayatian SM, Rezaeiniya H (2013) A novel hybrid social media platform selection model using fuzzy ANP and COPRAS-G. Expert Systems with Applications 40(14): 56945702.

97. Li GD, Yamaguchi D, Nagai M (2007) A grey-based decision-making approach to the supplier selection problem. Mathematical and computer modelling 46(3-4): 573-581.

98. Lee I, Lee K (2015) The Internet of Things (IoT): Applications, investments, and challenges for enterprises. Business horizons 58(4): 431-440.

99. Chen SH (1999) Ranking generalized fuzzy number with graded mean integration. Proceedings of international fuzzy systems association world congress.

100. Wu Y, Xu C, Zhang B, Tao Y, Li X, Chu H, Liu F (2019) Sustainability performance assessment of wind power coupling hydrogen storage projects using a hybrid evaluation technique based on interval type-2 fuzzy set. Energy, 179, 1176-1190.

101. Oztaysi B, Onar SC, Kahraman C (2017) Prioritization of business analytics projects using interval type2 fuzzy AHP. In Advances in Fuzzy Logic and Technology (pp. 106-117).

102. Debnath J, Majumder D, Biswas A (2018) Air quality assessment using weighted interval type-2 fuzzy inference system. Ecological Informatics 46, 133-146

103. Adhikary DD, Bose GK, Bose D, Mitra S (2014) Multi criteria FMECA for coal-fired thermal power plants using COPRAS-G. International Journal of Quality \& Reliability Management 31(5): 601-614

104. Ecer F (2014) A hybrid banking websites quality evaluation model using AHP and COPRAS-G: a Turkey case. Technological and Economic Development of Economy 20(4), 758-782.

105. Tavana M, Momeni E, Rezaeiniya N, Mirhedayatian SM, Rezaeiniya H (2013) A novel hybrid social media platform selection model using fuzzy ANP and COPRAS-G. Expert Systems with Applications 40(14), 5694-5702

106. Liou JJ, Tamošaitienè J, Zavadskas EK, Tzeng GH (2016) New hybrid COPRAS-G MADM Model for improving and selecting suppliers in green supply chain management. International Journal of Production Research 54(1), 114-134. 
Figures

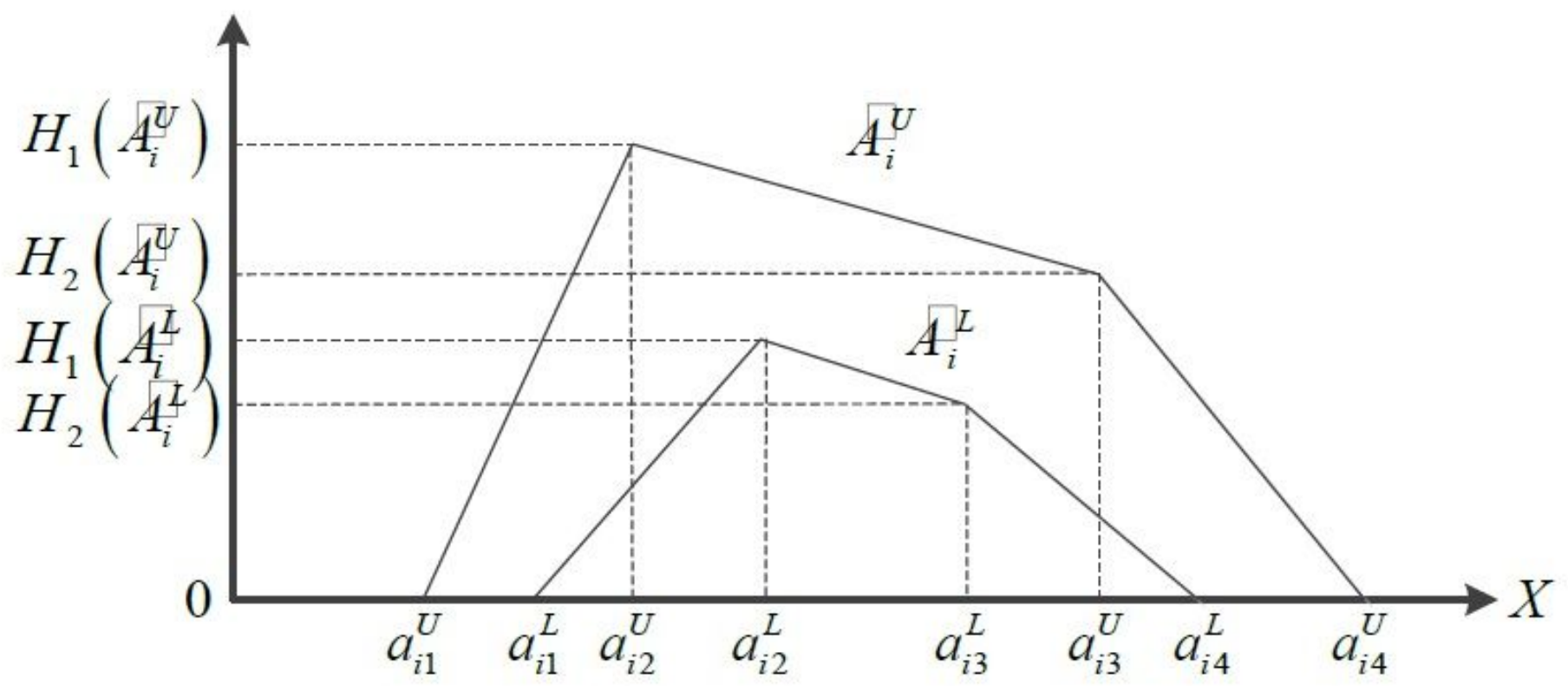

Figure 1

The membership functions of the interval type-2 fuzzy set 


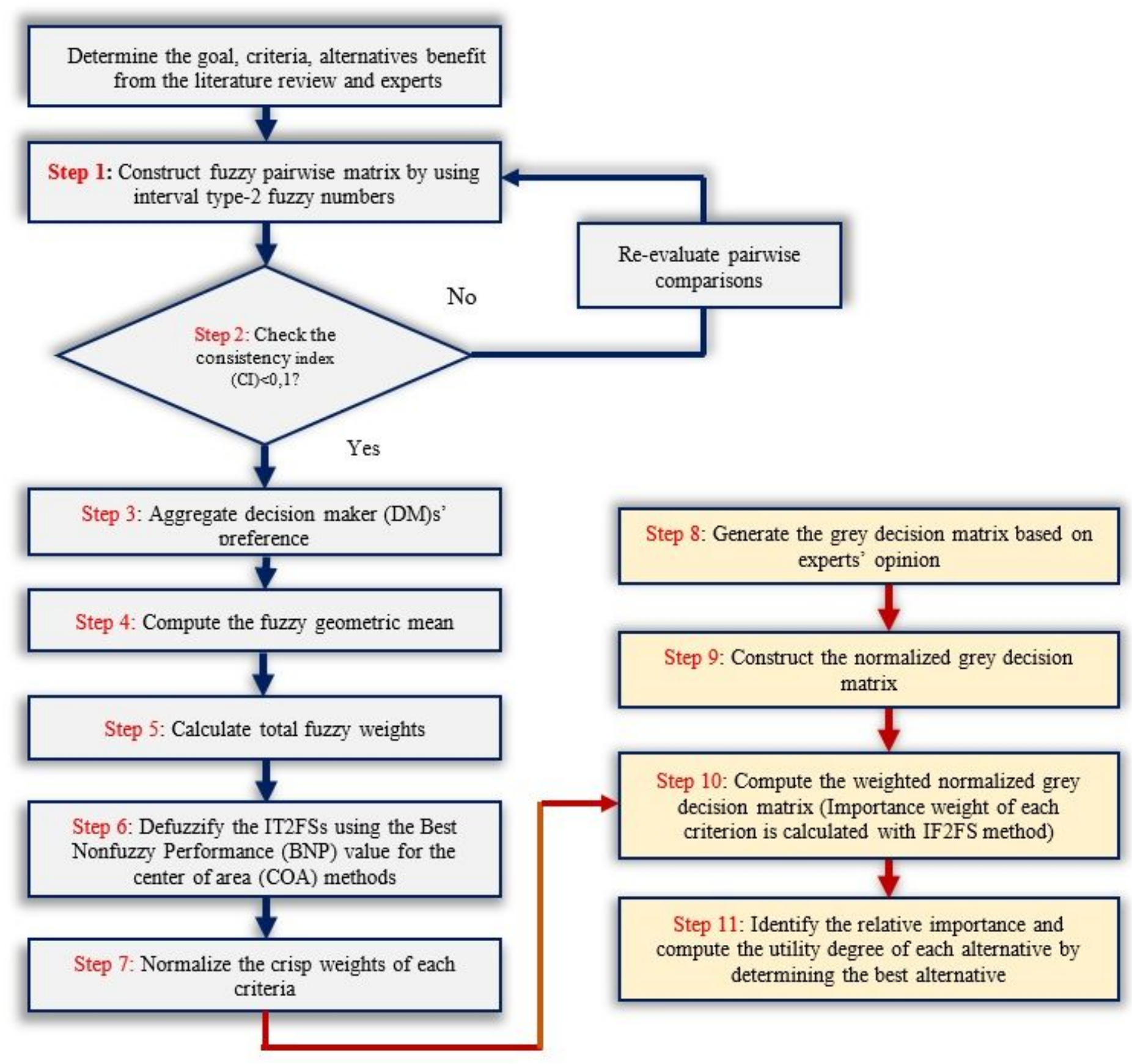

Figure 2

Systematic steps of the proposed methodology 


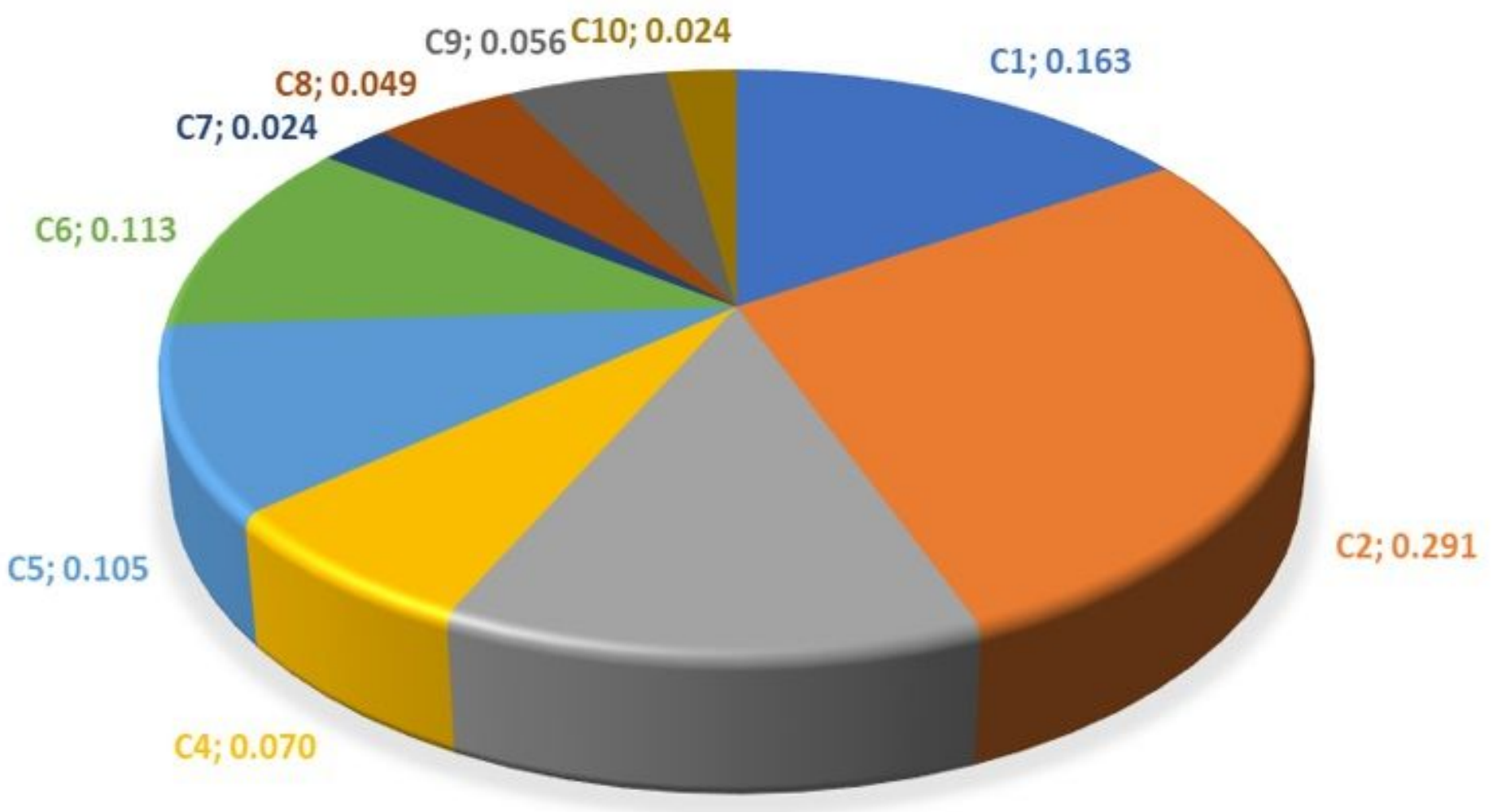

C3; 0.132

Figure 3

IT2FS and normalized weights of the criteria

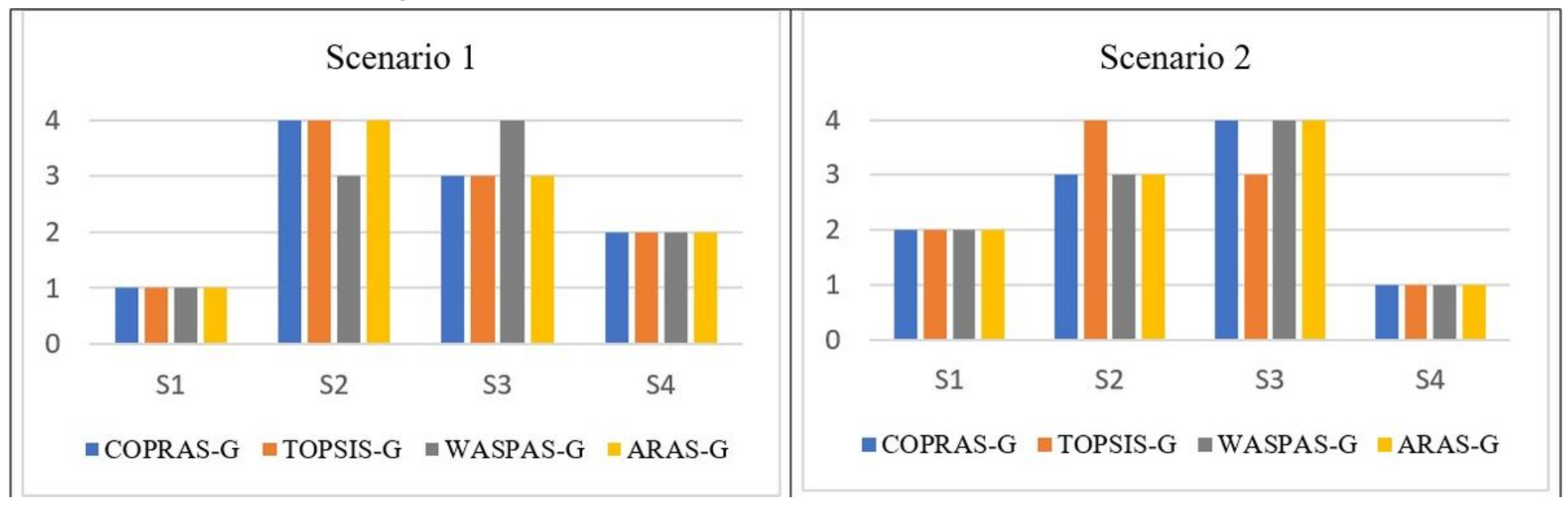

Figure 4

The ranking of suppliers (Scenario 1 and Scenario 2) 